\title{
The Drawdown of Personal Retirement Assets
}

\section{Citation}

Poterba, James M., Steven F. Venti, and David A. Wise. 2011. The Drawdown of Personal Retirement Assets. HKS Faculty Research Working Paper Series RWP11-006, John F. Kennedy School of Government, Harvard University

\section{Published Version}

http://web.hks.harvard.edu/publications/workingpapers/citation.aspx?Publd=7591

\section{Permanent link}

http://nrs.harvard.edu/urn-3:HUL.InstRepos:4677548

\section{Terms of Use}

This article was downloaded from Harvard University's DASH repository, and is made available under the terms and conditions applicable to Other Posted Material, as set forth at http:// nrs.harvard.edu/urn-3:HUL.InstRepos:dash.current.terms-of-use\#LAA

\section{Share Your Story}

The Harvard community has made this article openly available.

Please share how this access benefits you. Submit a story.

Accessibility 


\title{
The Drawdown of Personal Retirement Assets Faculty Research Working Paper Series
}

\author{
James M. Poterba
}

NBER

\author{
Steven F. Venti
}

Dartmouth College and NBER

\section{David A. Wise}

Harvard Kennedy School and NBER

\section{January 2011 RWP11-006}

The views expressed in the HKS Faculty Research Working Paper Series are those of the author(s) and do not necessarily reflect those of the John F. Kennedy School of Government or of Harvard University. Faculty Research Working Papers have not undergone formal review and approval. Such papers are included in this series to elicit feedback and to encourage debate on important public policy challenges. Copyright belongs to the author(s). Papers may be downloaded for personal use only. 
NBER WORKING PAPER SERIES

THE DRAWDOWN OF PERSONAL RETIREMENT ASSETS

James M. Poterba

Steven F. Venti

David A. Wise

Working Paper 16675

http://www.nber.org/papers/w16675

\author{
NATIONAL BUREAU OF ECONOMIC RESEARCH \\ 1050 Massachusetts Avenue \\ Cambridge, MA 02138 \\ January 2011
}

This research was supported by the U.S. Social Security Administration through grants \#10-P-98363-1-05 and \#10-M-98363-1-01 to the National Bureau of Economic Research as part of the SSA Retirement Research Consortium. Funding was also provided through grant number P01 AG005842 from the National Institute on Aging. Poterba is a trustee of the TIAA-CREF mutual funds and the College Retirement Equity Fund, a retirement service provider. We are grateful to John Sabelhaus and especially Sarah Holden for helpful comments and discussion. The findings and conclusions expressed are solely those of the authors and do not represent the views of the SSA, any agency of the Federal Government, TIAA-CREF, or the NBER.

(C) 2011 by James M. Poterba, Steven F. Venti, and David A. Wise. All rights reserved. Short sections of text, not to exceed two paragraphs, may be quoted without explicit permission provided that full credit, including $\odot$ notice, is given to the source. 
The Drawdown of Personal Retirement Assets

James M. Poterba, Steven F. Venti, and David A. Wise

NBER Working Paper No. 16675

January 2011

JEL No. D14,E21,H30,J14

\begin{abstract}
How households draw down the balances that they accumulate in retirement saving accounts such as 401(k) plans and Individual Retirement Accounts can have an important effect on the contribution of these accounts to retirement income security. This paper presents evidence on the pattern of withdrawals at different ages. We find a relatively modest rate of withdrawals prior to the age at which households are required to take minimum required distributions. Only seven percent of PRA-owning households between the ages of 60 and 69 take annual distributions of more than ten percent of their PRA balance, and only 18 percent of PRA households in this age group make any withdrawals in a typical year. The rate of distributions rises sharply after age $70 \frac{1}{2}$, when minimum distributions are required. The proportion of PRA-owning households making a withdrawal jumps to over 60 percent by age 71 , and crosses 70 percent a few years later. On average, households age 60 to 69 with PRA accounts withdraw only about two percent of their account balances each year, considerably less than the rate of return on account balances during our sample period. Even at older ages - after the required minimum distribution age--the percentage of balances withdrawn remains at about five percent.
\end{abstract}

James M. Poterba

NBER

1050 Massachusetts Ave

Cambridge, MA 02138

poterba@mit.edu

Steven F. Venti

Department of Economics

6106 Rockefeller Center

Dartmouth College

Hanover, NH 03755

and NBER

steven.f.venti@dartmouth.edu
(1)

David A. Wise

Harvard University and NBER

1050 Massachusetts Avenue

Cambridge, MA 02138-5398

and NBER

dwise@nber.org 
Just three decades ago retirement saving in the United States was based heavily on employer-provided defined benefit plans. Benefits after retirement were typically received in the form of lifetime annuities. Today, personal retirement accounts (PRAs), which include 401(k)s, IRAs, Keoghs, and similar plans, have become the primary form of retirement saving for private-sector workers. In 2008, according to the Brady, Holden and Short (2009), private sector PRA assets totaled \$7.1 trillion while assets in traditional defined benefit programs totaled $\$ 2.0$ trillion. At the time of retirement, the PRA participant typically has sole control of the accumulated assets and can decide when to withdraw them. To date, assets held in PRAs have rarely been annuitized. This has raised concern that some participants will draw down assets precipitously and outlive their retirement assets. In this paper, we present new evidence on how PRA assets are drawn down, focusing in particular on patterns in the early years of retirement.

Our work complements a number of recent studies that have investigated both the post-retirement utilization of PRAs and related issues of wealth accumulation or draw-down at older ages. Bryant, Holden, and Sabelhaus (2010) use tax return data to study withdrawals from IRAs and defined contribution pension plans before plan beneficiaires reach age 60 . They find such distributions equal roughly 2.5 percent of underlying assets in recent years. Bershadker and Smith (2006) examine withdrawals from IRAs using tax returns for 2002. They find that nearly half of taxpayers do not make any IRA withdrawals within the first two years of retirement, and they find that a substantial group of IRA holders waits until age $70 \frac{1}{2}$, the age at which required minimum distributions must commence, before making any withdrawals. Love and Smith (2007) compare balances in IRAs and defined contribution retirement plans for households in several waves of the Health and Retirement Survey, and they find that the annuitized value of wealth rises from one wave to the next for most households.

It is important to distinguish between research on the age-related evolution of assets in retirement saving plans, and studies of age-wealth profiles more generally. Hurd (2002) studies a sample of households in the Asset and Health Dynamics among the Oldest Old (AHEAD) survey, and finds that total wealth declines with age when computed from a cross-section, but increases when computed from a panel. His study is one of the few that calculates profiles for individual categories of assets. He finds that the same pattern of positive wave-to-wave changes holds for most asset categories including IRAs. He attributes the difference between cross-section and panel results to the presence of substantial cohort effects. These cohort effects are particularly large for PRA assets because IRAs, 401(k)s and similar programs were not available to older persons. Several other studies focus on the evolution of total wealth after retirement. French, Doctor, and Baker (2007), using the AHEAD survey, find a modest decline in household wealth over the 1996-2004 period. Love, Palumbo and Smith (2008) convert financial and non-financial assets -- including annuities from Social Security and DB pensions - into a measure of "annualized comprehensive wealth." They find that this measure of wealth tends to rise with age following retirement. A recent study by Hurd and Rohwedder (2010) calculates several different measures of wealth and saving and finds evidence that total wealth declines with age 
for singles, but not for couples. With the exception of Hurd (2002), none of these studies separately distinguishes wealth held in PRAs from wealth held in other settings. Poterba, Venti, and Wise (2010a) suggest that wealth trajectories vary substantially across older households, with family status transitions playing a particularly important role in distinguishing those with rising and stable or declining wealth. Studying the evolution of PRA assets, as we do in the current paper, does not directly address the question of how total wealth evolves in retirement. Since retirement plan assets represent the largest source of financial assets for a substantial share of retirees, however, whether these assets are preserved is a potentially important issue for a substantial group of older households.

The current exploration of draw-down patterns from PRAs parallels earlier investigations of the draw-down of housing equity. Venti and Wise $(1990,2001,2004)$ found that home equity was typically not used to support general consumption in retirement, but instead tended to be used in the event of shocks to family status, like death of a spouse, or entry into a nursing home. They concluded that home equity, the primary asset of a large fraction of families, was conserved for a "rainy day." Megbolugbe, Sa-Aadu, and Shilling (1997) and Banks, Blundell, Oldfield and Smith (2007) also find that the drawdown of home equity is typically associated with shocks. Davidoff (2007) suggests that one reason for the slow draw-down of housing equity is the desire of homeowners to preserve their home equity as a potential source of funding for large health expenses.

Our analysis relies primarily on data from the Survey of Income and Program Participation (SIPP), but it also draws on information in the Health and Retirement Study (HRS). Our central finding is that PRA assets, like home equity, tend to be conserved in the early retirement years. Withdrawal rates are low following retirement until account-holders attain age of $701 / 2$, the age at which required minimum distributions (RMDs) from traditional IRAs and 401(k) plans must begin. At age 70 1/2, the proportion of households reporting withdrawals jumps from about 20 percent to over 60 percent. Despite the large jump in the probability that assets are withdrawn at this age, the overall proportion of assets withdrawn continues to be a small proportion of the PRA balance. This withdrawal ratio averages between one and two percent between ages 60 and 69 , and rises to about 5 percent at age $701 / 2$. It fluctuates around that level through age 85 . When investment returns and contributions to PRAs from the subset of households in this age range who are still employed exceed this withdrawal rate, it is possible for average PRA assets to rise with age, even after age $70 \frac{1}{2}$. This is the pattern that we observe for the time period we investigate. This result supports our second broad finding: while there is substantial heterogeneity across households, only a small proportion of households draw down PRA assets precipitously either before or after age $701 / 2$.

The paper is divided into six sections. In the first, we describe the growth of PRAs, using a cohort description of the data, and we emphasize the strong relationship between individual attributes-earnings, non-PRA wealth, health status, and other attributes-and the probability of having a PRA. In section two, we describe the 
evolution of within-cohort PRA balances as each cohort ages. We find that assets increase with age even after retirement. We also report the relationship between PRA assets and household attributes such as marital status, income, assets and health. In the next three sections we consider the withdrawal of PRA assets in more detail. Section three explores the relationship between household attributes and the probability that a household with a PRA makes a withdrawal from the account. Section four presents evidence on the percent of the PRA balance that is withdrawn, conditional on a withdrawal. The fifth section reports summary information on the proportion of households that withdraw more than a given percent of their PRA balance in a given year. This offers evidence on the proportion of households that are drawing down their PRA assets rapidly. There is a brief conclusion.

\section{SIPP Data for Tracking PRA Ownership}

We describe the spread of PRA accounts using SIPP data organized by cohort. The SIPP data are available for calendar years 1997, 1998, 1999, 2001, 2002, 2004 and 2005. ${ }^{1}$ We define PRA assets as the sum of the responses to the three SIPP questions that ask about holdings of "IRAs", "Keoghs" and "401(k), 403(b) or thrift plans". Summary data on the number of observations, PRA participation rates and PRA assets, by age and by year are presented in Table 1-1. In this table the "age" of two-person households is assumed to be the age of the male household member. For consistency with our subsequent tables, in which we consider withdrawals from PRA plans in the twelve months after the balance is reported, Table 1-1 only includes households who remained in the sample for at least twelve months after the PRA balance was reported. ${ }^{2}$

Simple comparisons of the findings from various waves of the SIPP show that the likelihood of respondents having assets in a personal retirement account, and the mean PRA balance (in $\$ 2000$ ), increase over time. In each wave of the survey, both the probability of PRA ownership and the average PRA balance conditional on ownership decline with age.

For tracking the evolution of PRA participation and for analyzing how account balances vary for PRA participants as they age, it is helpful to organize the SIPP data

\footnotetext{
${ }^{1}$ The 1997, 1998 and 1999 data are from waves 3, 6, and 9 of the 1996 SIPP panel. The 2001 and 2002 data are from waves 3 and 6 of the 2001 SIPP panel. The 2004 and 2005 data are from waves 3 and 6 of the 2004 SIPP panel.

${ }^{2}$ Restricting the sample to include only respondents who remain in the sample for 12 months after the PRA balance is reported excludes between 11 and 17 percent of the respondent in each year between 1997 and 2004. For 2005, 61 percent of the respondents are excluded because the sample size was reduced beginning with wave 8 of the 2004 panel. A second restriction is also applied. For about two percent of the sample the sum of monthly withdrawals exceeds the initial asset balance, typically because the household reports a zero initial PRA balance, but positive subsequent withdrawals. These respondents may have established new "rollover" PRAs (perhaps cash-outs from DB pensions) in the subsequent 12 months. We have also excluded these respondents from the analysis.
} 
by cohort. For example, we can obtain data for 60-year-old households in 1997, 61year-old households in 1998, and track this cohort through 68-year-old households in 2005. We identify each cohort by its age in 1997: "C60" refers to the cohort that was age 60 in 1997. These cohort data contain data from three distinct panel data sets that span shorter time periods. The same persons responded to the SIPP surveys in 1997, 1998, 1999, and 2000. Another sample responded in 2001 and 2002, and a third sample responded in 2004 and 2005. We treat the nine-year cohort data set as though it is drawn from a synthetic panel.

\begin{tabular}{|c|c|c|c|c|c|}
\hline \multirow{2}{*}{ Year } & \multicolumn{5}{|c|}{ Age interval } \\
\hline & $50-59$ & $60-69$ & $70-79$ & $80-85$ & All \\
\hline \multicolumn{6}{|c|}{ Number of observations } \\
\hline 1997 & 4,821 & 3,484 & 3,308 & 1,800 & 13,413 \\
\hline 1998 & 4,615 & 3,330 & 3,178 & 1,195 & 12,318 \\
\hline 1999 & 4,778 & 3,294 & 3,167 & 1,183 & 12,422 \\
\hline 2001 & 4,554 & 3,039 & 2,556 & 1,135 & 11,284 \\
\hline 2002 & 4,576 & 3,097 & 2,523 & 1,062 & 11,258 \\
\hline 2004 & 6,810 & 4,594 & 3,454 & 2,447 & 17,305 \\
\hline 2005 & 3,157 & 2,105 & 1,600 & 789 & 7,651 \\
\hline All & 33,311 & 22,943 & 19,786 & 9,611 & 85,651 \\
\hline \multicolumn{6}{|c|}{ Percent with positive PRA balance } \\
\hline 1997 & 43.8 & 38.6 & 24.0 & 6.6 & 32.6 \\
\hline 1998 & 45.5 & 40.4 & 26.4 & 10.5 & 36.1 \\
\hline 1999 & 46.8 & 40.0 & 27.8 & 13.1 & 37.3 \\
\hline 2001 & 49.4 & 41.0 & 30.0 & 16.9 & 39.7 \\
\hline 2002 & 50.6 & 44.4 & 30.7 & 19.2 & 41.8 \\
\hline 2004 & 57.3 & 50.2 & 37.9 & 18.6 & 46.3 \\
\hline 2005 & 56.5 & 51.9 & 35.7 & 22.7 & 47.8 \\
\hline All & 50.0 & 43.4 & 29.9 & 15.0 & 40.0 \\
\hline \multicolumn{6}{|c|}{ Mean PRA balance } \\
\hline 1997 & $\$ 25,491$ & $\$ 26,069$ & $\$ 13,173$ & $\$ 2,747$ & $\$ 19,620$ \\
\hline 1998 & $\$ 30,593$ & $\$ 29,341$ & $\$ 15,849$ & $\$ 4,983$ & $\$ 24,181$ \\
\hline 1999 & $\$ 37,848$ & $\$ 35,836$ & $\$ 20,980$ & $\$ 8,709$ & $\$ 30,557$ \\
\hline 2001 & $\$ 42,610$ & $\$ 38,656$ & $\$ 21,799$ & $\$ 11,234$ & $\$ 33,917$ \\
\hline 2002 & $\$ 37,382$ & $\$ 42,557$ & $\$ 24,693$ & $\$ 12,384$ & $\$ 33,803$ \\
\hline 2004 & $\$ 52,953$ & $\$ 54,460$ & $\$ 38,005$ & $\$ 15,489$ & $\$ 45,216$ \\
\hline 2005 & $\$ 57,367$ & $\$ 64,251$ & $\$ 39,415$ & $\$ 20,201$ & $\$ 51,980$ \\
\hline All & $\$ 40,468$ & $\$ 40,675$ & $\$ 23,631$ & $\$ 10,512$ & $\$ 33,554$ \\
\hline \multicolumn{6}{|c|}{ Number of observations (households with a PRA) } \\
\hline 1997 & 2,036 & 1,264 & 733 & 111 & 4,144 \\
\hline 1998 & 2,047 & 1,269 & 777 & 117 & 4,210 \\
\hline 1999 & 2,203 & 1,242 & 821 & 143 & 4,409 \\
\hline 2001 & 2,202 & 1,182 & 723 & 184 & 4,291 \\
\hline 2002 & 2,238 & 1,300 & 724 & 197 & 4,459 \\
\hline 2004 & 3,855 & 2,225 & 1,239 & 451 & 7,770 \\
\hline 2005 & 1,748 & 1,026 & 541 & 179 & 3,494 \\
\hline All & 16,329 & 9,508 & 5,558 & 1,382 & 32,777 \\
\hline \multicolumn{6}{|c|}{ Mean PRA balance (households with a PRA) } \\
\hline 1997 & 58190 & 67589 & 54999 & 41919 & 60110 \\
\hline 1998 & $\$ 67,217$ & $\$ 72,611$ & $\$ 60,067$ & $\$ 47,263$ & $\$ 67,043$ \\
\hline 1999 & $\$ 80,826$ & $\$ 89,667$ & $\$ 75,589$ & $\$ 66,305$ & $\$ 81,983$ \\
\hline 2001 & $\$ 86,241$ & $\$ 94,329$ & $\$ 72,675$ & $\$ 66,326$ & $\$ 85,417$ \\
\hline 2002 & $\$ 73,901$ & $\$ 95,845$ & $\$ 80,404$ & $\$ 64,475$ & $\$ 80,948$ \\
\hline 2004 & $\$ 92,464$ & $\$ 108,571$ & $\$ 100,150$ & $\$ 83,242$ & $\$ 97,705$ \\
\hline 2005 & $\$ 101,503$ & $\$ 123,708$ & $\$ 110,544$ & $\$ 88,864$ & $\$ 108,797$ \\
\hline All & $\$ 80,888$ & $\$ 93,621$ & $\$ 79,107$ & $\$ 69,897$ & $\$ 83,876$ \\
\hline
\end{tabular}


Figure 1-1 shows the percent of households with positive PRA balances for seven cohorts whose members were between the ages of 51 and 84 in 1997. The first (partial) cohort shown in the figure was 45 years old in 1997. Households in this cohort were observed only at age 52 in 2004 and at age 53 in 2005. The first complete cohort shown in the figure was 51 years old in 1997. When first observed at age 51, 44 percent of the households in this cohort had positive PRA balances. By 2005, when they were 59, 56.4 percent had positive PRA balances.

This figure shows large differences between cohorts, which we interpret as "cohort effects." Younger cohorts, those who reach a given age in a later year, are more likely to have a PRA than older cohorts. For example, 56.4 percent of the households that were 59 years old in 2005 had a PRA positive balance, but six years earlier, only 45 percent of the 59 -year-old households had a PRA. This "cohort effect" equals the vertical distance between the two circled observations in the figure.

The presence of substantial cohort effects is not surprising given the growth of retirement saving plans during the last three decades. IRAs became broadly available in 1981, and 401 (k) plans were not widely embraced by corporations until the early 1980s, although many firms did not adopt them until much later. Workers who were 51 years old in 2005 were 28 in 1982, so they were potentially "exposed" to 401(k) plans for 23 years. In contrast, 83 year olds in 1999 were 66 in 1982; they are much less likely to have been able to participate in a retirement saving plan before they retired.

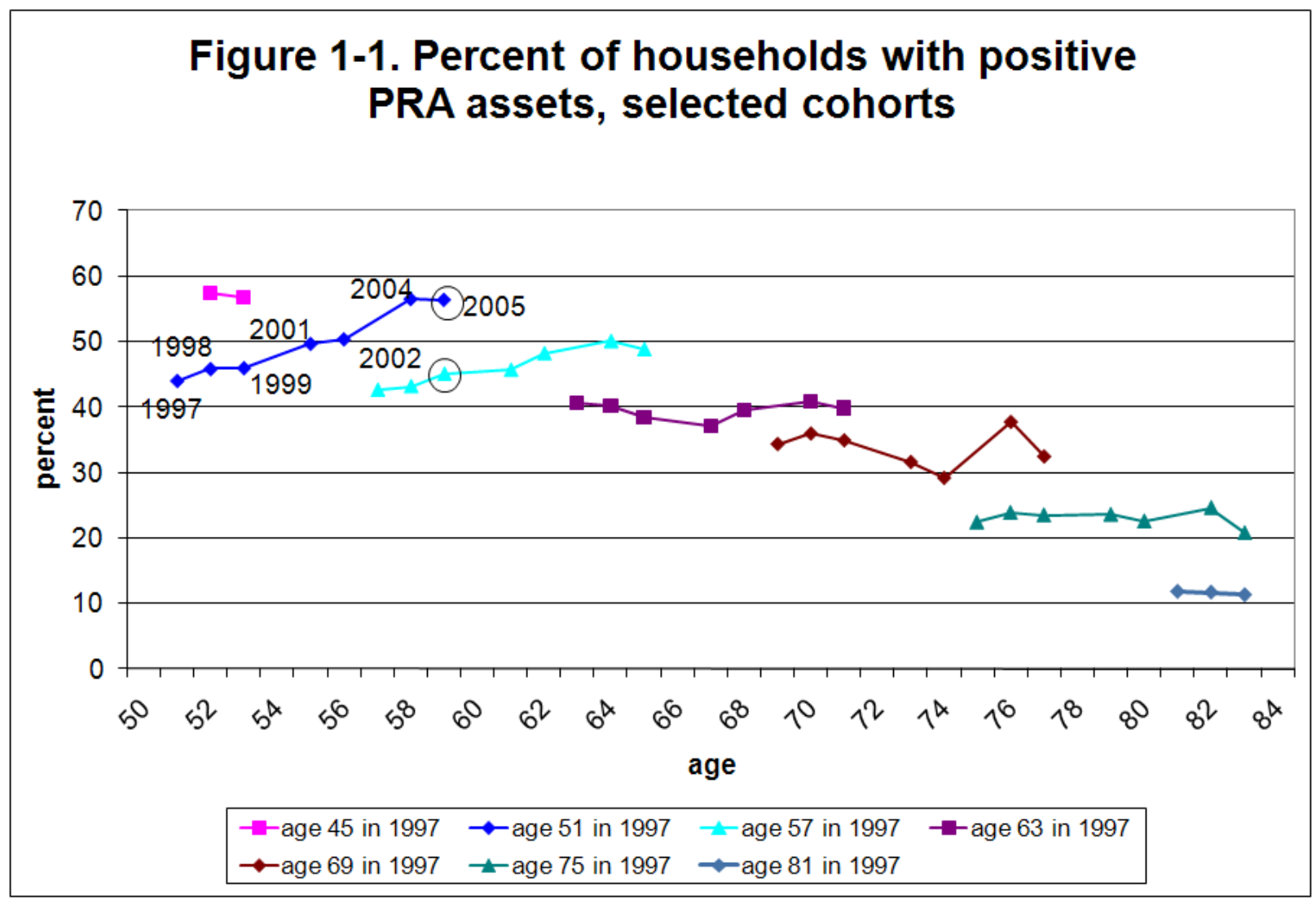


While Figure 1-1 highlights the rapid spread of PRAs in the past three decades, it does not reveal the correlations of PRA ownership with household attributes such as earnings, non-PRA wealth holdings, and health status. These correlations can be important for understanding the evolution of PRA ownership, since it is possible that some of the age-related or cohort-related variation in PRA ownership rates may reflect age-varying or cohort-varying household attributes that are predictive of PRA ownership. These correlations are also important for the information that they provide about the attributes of the households who are making decisions about whether to draw down PRA assets.

To summarize the relationship between PRA ownership and various household attributes, we estimate probit models relating an indicator variable for whether a household has a positive PRA balance to a set of indicator variables for household age, a set of indicator variables for cohort (again measured as age of household head in 1997), and a set of other household attributes. The latter includes an indicator variable for whether the household is retired, an indicator variable for marital status, a measure of self-reported health status, earned income, annuity income, housing wealth, and non-housing wealth. Since we have chosen to include both age and cohort effects in our specification, we cannot separately identify time effects.

Table 1-2 presents estimates of the resulting probit specifications, showing in each case the marginal relationship between each household attribute and the probability of having a PRA. The first column reports estimated age and cohort effects without controlling for other household attributes; it essentially replicates the profiles shown in Figure 1-1. Each cohort includes households in a three year age window. For example, cohort C54 includes cohorts C53, C54, and C55. The difference between the probability derivatives for the $\mathrm{C} 42$ cohort (the base cohort) and the $\mathrm{C} 84$ cohort is 0.855: a household in the oldest cohort in 1997 has an 85.5 percent lower probability of having a PRA, all else equal, than a household in the youngest cohort in 1997.

In modeling age effects, we allow for differences before and after a household reaches age 63. We do this with a piecewise linear function with a break at age 63 . The probability of having a PRA increases with age through age 63 , but there is little effect of age after age 63. This is consistent with PRA accounts being opened while households are employed, but not after retirement.

The specification in the second column of Table 1-2 adds variables corresponding to five sets of household attributes to the specification in the first column. The first set of variables, in this case only a single variable, is an indicator for whether the household is retired or still working. In the case of married households, we make this determination based on whether the husband is still working. The second set of variables describes the household's marital status--single female, single male, or married. The third set of variables describes household income; we distinguish earned income and annuity income. The fourth set of variables describes household wealth, which we divide into housing wealth and non-housing, non-PRA wealth. The fifth set of 
variables captures self-reported health status. Each respondent can indicate poor, fair, good, very good, or excellent. We collapse these responses into two categories, "very good or excellent" and "fair or poor" ("good" is the excluded category). Estimates for each of the health status groups are obtained separately for single persons, married males and married females. Finally, all of the attributes are interacted with an indicator for whether the household is above or below the age of 63 . We use this same set of household attributes in later explorations of PRA asset balances and withdrawal behavior, although in some case we replace the interaction with pre- and post-age 63 with an interaction with different age breaks.

\begin{tabular}{|c|c|c|c|c|c|c|c|c|c|}
\hline \multirow[b]{2}{*}{ spline in age } & \multicolumn{2}{|l|}{ (1) } & \multicolumn{2}{|c|}{$(2)$} & \multirow{2}{*}{ Variable } & \multicolumn{2}{|c|}{ (1) } & \multicolumn{2}{|c|}{ (2) } \\
\hline & Coef & Z- & Coef & Z-score & & Coef & Z-score & Coef & Z-score \\
\hline Age $\leq 63$ & 0.012 & 11.64 & 0.017 & 14.33 & VG or excellent if age $\leq 63$ & & & 0.115 & 13.00 \\
\hline Age $>63$ & -0.001 & -1.33 & -0.005 & -4.48 & VG or excellent if age $>63$ & & & 0.066 & 7.28 \\
\hline cohort effects & & & & & Fair or poor if age $\leq 63$ & & & -0.217 & -19.34 \\
\hline Age 45 in 1997 & -0.043 & -2.57 & -0.048 & -2.61 & Fair of poor if age $>63$ & & & -0.169 & -16.91 \\
\hline Age 48 in 1997 & -0.084 & -5.20 & -0.097 & -5.36 & health status - married male & & & & \\
\hline Age 51 in 1997 & -0.123 & -7.66 & -0.148 & -8.17 & VG or excellent if age $\leq 63$ & & & 0.013 & 1.43 \\
\hline Age 54 in 1997 & -0.155 & -8.86 & -0.180 & -9.11 & VG or excellent if age $>63$ & & & 0.025 & 2.40 \\
\hline Age 57 in 1997 & -0.226 & -11.87 & -0.258 & -12.04 & Fair or poor if age $\leq 63$ & & & -0.106 & -9.21 \\
\hline Age 60 in 1997 & -0.269 & -13.30 & -0.290 & -12.92 & Fair of poor if age $>63$ & & & -0.085 & -7.99 \\
\hline Age 63 in 1997 & -0.320 & -15.17 & -0.332 & -14.12 & health status - married female & & & & \\
\hline Age 66 in 1997 & -0.350 & -16.04 & -0.327 & -13.34 & VG or excellent if age $\leq 63$ & & & 0.058 & 6.59 \\
\hline Age 69 in 1997 & -0.371 & -16.41 & -0.316 & -12.60 & VG or excellent if age $>63$ & & & 0.064 & 6.33 \\
\hline Age 72 in 1997 & -0.408 & -17.05 & -0.324 & -12.25 & Fair or poor if age $\leq 63$ & & & -0.051 & -4.42 \\
\hline Age 75 in 1997 & -0.484 & -18.80 & -0.380 & -13.36 & Fair of poor if age $>63$ & & & -0.071 & -6.53 \\
\hline Age 78 in 1997 & -0.580 & -20.81 & -0.436 & -14.20 & Intercept & -0.553 & -10.04 & -1.069 & -16.54 \\
\hline Age 81 in 1997 & -0.669 & -21.85 & -0.528 & -15.66 & & & & & \\
\hline Age 84 in 1997 & -0.855 & -23.10 & -0.671 & -16.38 & number of observations & 85,651 & & 85,651 & \\
\hline self-reported retirement status & & & & & Wald chi2(2) & 4,986 & & 11,694 & \\
\hline retired if age $\leq 63$ & & & 0.029 & 3.60 & Prob > chi 2 & 0.0000 & & 0.0000 & \\
\hline retired if age $>63$ & & & -0.081 & -8.31 & Pseudo R2 & 0.0555 & & 0.2009 & \\
\hline marital status & & & & & & & & & \\
\hline Single male if age $\leq 63$ & & & -0.057 & -6.83 & & & & & \\
\hline Single male if age $>63$ & & & -0.008 & -0.89 & & & & & \\
\hline Married if age $\leq 63$ & & & 0.059 & 5.15 & & & & & \\
\hline Married if age $>63$ & & & 0.096 & 8.82 & & & & & \\
\hline income & & & & & & & & & \\
\hline Earned income if age $\leq 63$ & & & 0.036 & 18.32 & & & & & \\
\hline Earned income if age $>63$ & & & 0.024 & 9.34 & & & & & \\
\hline Annuity income if age $\leq 63$ & & & 0.016 & 4.82 & & & & & \\
\hline $\begin{array}{l}\text { Annuity income if age }>63 \\
\text { wealth (in 10,000's) }\end{array}$ & & & 0.069 & 24.46 & & & & & \\
\hline Housing wealth if age $\leq 63$ & & & 0.005 & 15.17 & & & & & \\
\hline Housing wealth if age $>63$ & & & 0.007 & 23.83 & & & & & \\
\hline Nonhousing wealth if age $\leq 63$ & & & 0.001 & 4.41 & & & & & \\
\hline Nonhousing wealth if age>63 & & & 0.000 & 2.37 & & & & & \\
\hline
\end{tabular}

The estimates suggest that there are substantial differences across households with different attributes in the probability of PRA ownership. Two findings deserve particular note. First, the reduction in the estimated cohort effects when household attributes are added suggests that the cohort effects estimated in the first column reflect, in part, the change over time in household attributes. The addition of household attributes reduces the difference between the youngest and oldest (omitted) cohort from 0.855 to 0.671 . This difference appears primarily to be the result of including 
income and wealth variables in the specification. Second, holding other attributes constant, the marginal estimates together with the associated z-scores show that married households, those with greater earned income, with greater annuity income, and with greater wealth in either housing equity or other assets are more likely to report a positive PRA balance. Persons in better health are also more likely to have a PRA.

To illustrate the quantitative importance of these findings, we can focus on several examples. Among those under 63 years of age, a married person is 11.6 percent more likely to have a PRA than a single man is. For someone under the age of 63 , a $\$ 10,000$ increase in earned income is associated with a 3.6 percent increase in the probability of having a PRA. For persons over the age of 63 , and likely to be retired, a $\$ 10,000$ increase in annuity income is associated with a 6.9 percent increase in the probability of having a PRA. For persons under the age of 63 , each $\$ 10,000$ increase in housing wealth is associated with roughly a 0.5 percentage point increase in the probability of having a PRA; the effect of the same addition to non-housing wealth is only about 0.1 percentage points.

The results in Table 1-2 also display a strong relationship between health status and the probability of PRA ownership. Controlling for the other household attributes that are included in the probit models, persons in poor health are much less likely than persons in good health to have a PRA. For example, among those who are not yet 63 years of age, single persons in very good or excellent health are 33 percent more likely to have a PRA than are those in fair or poor health. For married men (women) the difference is 12 (11) percent. This finding complements results in Poterba, Venti, and Wise (2010c) that suggest that households in good health near retirement age have higher lifetime earnings than those in poor health, greater earnings at retirement, greater annuity income after retirement, and more non-retirement account wealth.

To illustrate the findings in Table 1-2, in Table 1-3 we report the probability of PRA ownership for four hypothetical households with different sets of attributes. These probabilities are computed using the coefficient estimates that underlie the marginal probability effects in Table 1-2. We focus on households between the ages of 60 and 63 , and consider separately households who are not yet retired and households that are retired. We consider "low-percentile" households with low income $\left(10^{\text {th }}\right.$

\begin{tabular}{|c|c|c|}
\hline \multirow{2}{*}{$\begin{array}{l}\text { Attributes and } \\
\text { probability }\end{array}$} & \multicolumn{2}{|c|}{ Age } \\
\hline & 60 to 63 & 60 to 63 \\
\hline & \multicolumn{2}{|c|}{ Not retired } \\
\hline Marital status & Single Male. & Married \\
\hline Earned income & 10th pctile & 90th pctile \\
\hline Annuity income & 0 & 0 \\
\hline Housing wealth & 10th pctile & 90th pctile \\
\hline Nonhousing wealth & 10th pctile & 90th pctile \\
\hline Health & Fair-Poor & Ex-VG \\
\hline \multirow[t]{2}{*}{ Probability } & 0.083 & 0.804 \\
\hline & \multicolumn{2}{|c|}{ Retired } \\
\hline Marital status & Single Male. & Married \\
\hline Earned income & 0 & 0 \\
\hline Annuity income & 10th pctile & 90th pctile \\
\hline Housing wealth & 10th pctile & 90th pctile \\
\hline Nonhousing wealth & 10th pctile & 90th pctile \\
\hline Health & Fair-Poor & Ex-VG \\
\hline Probability & 0.095 & 0.632 \\
\hline
\end{tabular}


percentile), low wealth, and poor health, and "high-percentile" households with high income $\left(90^{\text {th }}\right.$ percentile), high wealth, and good health. The $10^{\text {th }}$ and $90^{\text {th }}$ percentiles approximate persons in the bottom and top quintiles of each attribute. For lowpercentile households that are not retired, the predicted probability of PRA ownership is only about 8 percent. By comparison, for the high-percentile non-retired households, the predicted probability is 80 percent. For retired households in this age range, about 10 percent of the low-percentile households are predicted to have a PRA, compared to about 63 percent of high-percentile households. These summary measures underscore the importance of household attributes in potentially explaining differences in PRA ownership.

\section{Balances in PRAs}

Since we are interested in the amount withdrawn from PRAs, we need to consider not just the ownership of these accounts but also the balances in these accounts. Figure 2-1 shows average PRA balances (in \$2000) at each age for selected cohorts labeled by the cohort age in 1997. As in our earlier analysis, the data are for $1997,1998,1999,2001,2002,2004$, and 2005 . The figure suggests two key conclusions. First, younger cohorts have higher average PRA asset levels at each age. Second, in most cases, within cohorts for which we have at least two years of data, assets tend to increase as the cohort ages. This pattern, while common, is not universal. Several cohorts show a decline in assets between 1999 and 2002, most likely reflecting the decline in stock prices following the dot-com bubble. The general pattern suggests that for most ages and cohorts, the increase in asset balances arising from new contributions and from returns on existing balances exceeds the reduction in assets due to withdrawals. In comparing the average PRA balances as cohorts age, but while many members of the cohort are still in the labor force, there are potentially four distinct effects at work: the investment return and contribution effects that increase existing PRA balances, the withdrawal effect that reduces them, and the "new account opening" effect that adds low-balance new accounts into the set of PRAs over which we average to compute the cohort mean PRA balance. Thus even if PRA balances rose for all existing PRA holders at a given age, it would still be possible in principle for the average PRA balance to decline as the cohort aged. Our findings suggest that this effect does not play a dominant role. 


\section{Figure 2-1. Mean PRA balances for households with a PRA, selected cohorts}

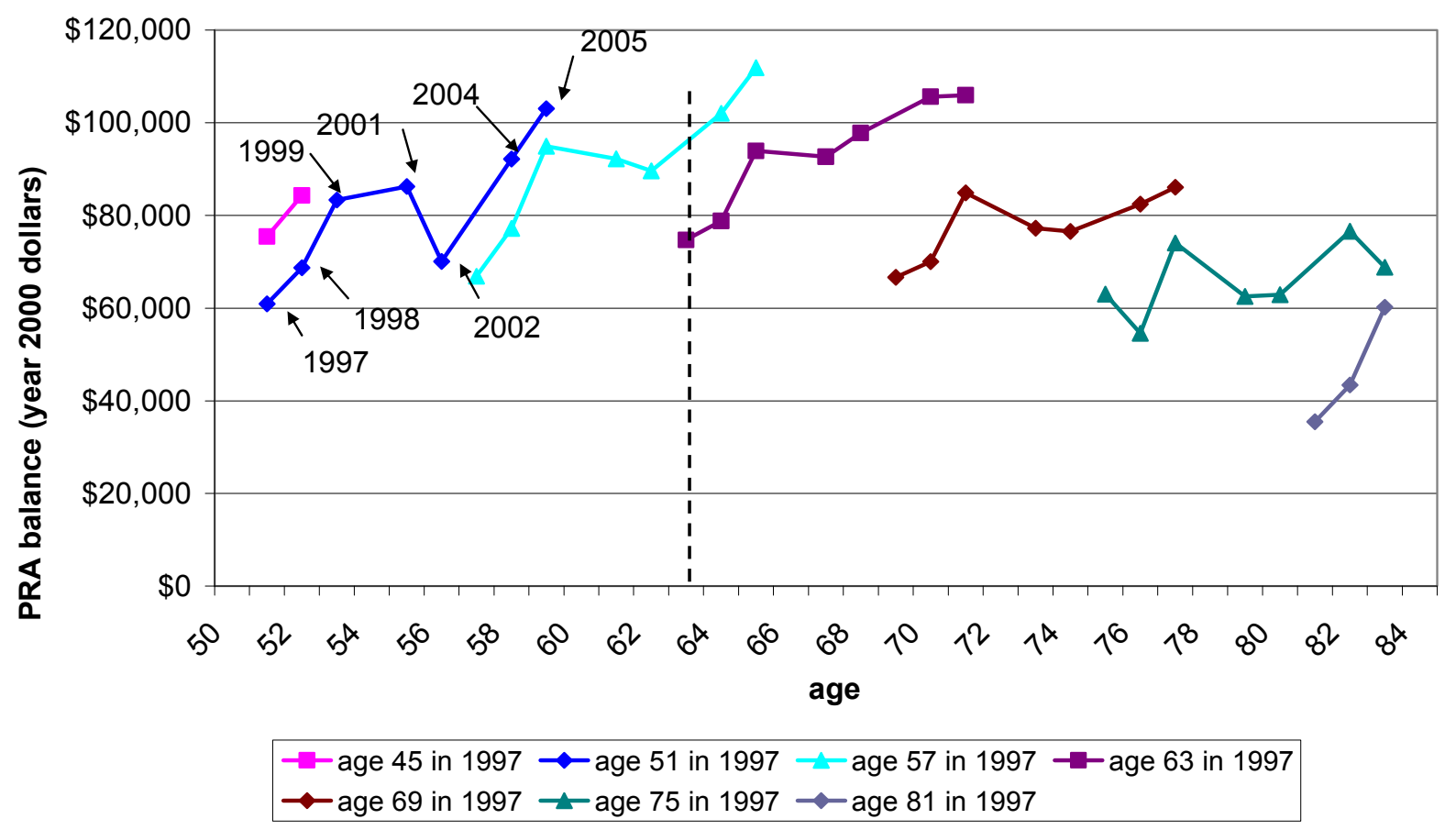

To identify the household attributes that are associated with high and low levels of PRA assets, we specify a simple model for these balances $(B)$ :

$$
B_{i}=\alpha e^{Z_{i} \gamma}+\varepsilon_{i}
$$

where $Z_{i}$ is a vector that includes age and cohort effects, as well as the same set of household attributes as in our foregoing analysis of the probability of reporting a positive PRA balance. Now, the estimated coefficients $(\gamma)$ are the estimated percentage change in $B$ that would be associated with a unit change in the corresponding $Z_{i}$ variable. We estimate (1) by nonlinear least squares (NLLS) for all households with a positive PRA balance. We also experimented with a log-linear counterpart to (1), estimating the log of $B_{i}$ as a linear function of the $Z_{i}$ variables. The fit of the model in (1) was substantially better than that of the corresponding log-linear model, so we report the estimates from it.

Table 2-1 reports the results of estimating (1) by NLLS. We begin in column one with a simple specification that includes only age and cohort effects, and then add the additional family attributes. The age estimates are specified as piecewise linear with breaks at 69 and 71 to allow for a change in asset evolution at the age of the required minimum distribution (RMD). For households below the age of 69 , the estimates 
indicate that PRA assets increase 4.3 percent per year. Between ages 69 and 71 , the age at which households must begin to make required minimum distributions (RMDs), the estimates show essentially no change in assets. At ages above 71, PRA assets increase at an average rate of 2.6 percent per year. These findings suggest that over our data period, asset returns and the contributions of our still-working sample members more than offset asset outflows due to withdrawals as well as the "small account opening effect" for working-age cohorts. We observe the pattern of rising average PRA balances both before and after cohorts reach age $701 / 2$ and need to begin RMD withdrawals. The estimates in column 1 also show substantial cohort effects, similar to those observed in Figure 2-1.

\begin{tabular}{|c|c|c|c|c|c|c|c|c|c|}
\hline \multicolumn{10}{|c|}{ Table 2-1 NLLS estimates of PRA balance for households with a PRA account, households age 50 to 85} \\
\hline \multirow{2}{*}{ spline in age } & \multicolumn{2}{|c|}{$(1)$} & \multicolumn{2}{|c|}{$(2)$} & \multirow{2}{*}{ Variable } & \multicolumn{2}{|c|}{ (1) } & \multicolumn{2}{|c|}{$(2)$} \\
\hline & Coef & Z-score & Coef & Z-score & & Coef & Z-score & Coef & Z-score \\
\hline Age $\leq 69$ & 0.043 & 12.84 & 0.029 & 7.47 & VG or excellent if age $\leq 69$ & & & 0.233 & 6.48 \\
\hline $69<$ age $\leq 71$ & -0.010 & -0.51 & 0.030 & 0.65 & VG or excellent if $69<$ age $<72$ & & & 0.161 & 1.34 \\
\hline Age $>71$ & 0.026 & 3.69 & 0.020 & 2.40 & VG or excellent if age $\geq 72$ & & & 0.169 & 2.35 \\
\hline cohort effects & & & & & Fair or poor if age $\leq 69$ & & & -0.126 & -2.06 \\
\hline Age 45 in 1997 & -0.027 & -0.46 & 0.044 & 0.67 & Fair or poor if $69<$ age $<72$ & & & -0.047 & -0.27 \\
\hline Age 48 in 1997 & -0.035 & -0.59 & 0.002 & 0.02 & Fair or poor if age $\geq 72$ & & & 0.095 & 1.05 \\
\hline Age 51 in 1997 & -0.117 & -1.98 & -0.063 & -0.97 & health status - married male & & & & \\
\hline Age 54 in 1997 & -0.184 & -2.93 & -0.100 & -1.44 & VG or excellent if age $\leq 69$ & & & 0.120 & 5.19 \\
\hline Age 57 in 1997 & -0.248 & -3.64 & -0.156 & -2.04 & VG or excellent if $69<$ age $<72$ & & & -0.206 & -2.23 \\
\hline Age 60 in 1997 & -0.360 & -4.87 & -0.221 & -2.68 & VG or excellent if age $\geq 72$ & & & 0.014 & 0.25 \\
\hline Age 63 in 1997 & -0.454 & -5.70 & -0.318 & -3.58 & Fair or poor if age $\leq 69$ & & & -0.201 & -4.87 \\
\hline Age 66 in 1997 & -0.624 & -7.41 & -0.409 & -4.41 & Fair or poor if $69<$ age $<72$ & & & -0.129 & -1.06 \\
\hline Age 69 in 1997 & -0.787 & -8.92 & -0.517 & -5.33 & Fair or poor if age $\geq 72$ & & & 0.096 & 1.38 \\
\hline Age 72 in 1997 & -0.879 & -9.33 & -0.590 & -5.65 & health status - married female & & & & \\
\hline Age 75 in 1997 & -1.087 & -10.43 & -0.745 & -6.41 & VG or excellent if age $\leq 69$ & & & 0.125 & 5.24 \\
\hline Age 78 in 1997 & -1.275 & -10.84 & -0.929 & -7.17 & VG or excellent if $69<$ age $<72$ & & & 0.259 & 2.59 \\
\hline Age 81 in 1997 & -1.356 & -9.56 & -1.049 & -6.64 & VG or excellent if age $\geq 72$ & & & 0.189 & 3.40 \\
\hline Age 84 in 1997 & -1.283 & -5.51 & -0.867 & -3.43 & Fair or poor if age $\leq 69$ & & & -0.059 & -1.53 \\
\hline self-reported retirement status & & & & & Fair or poor if $69<$ age $<72$ & & & -0.162 & -0.99 \\
\hline retired if age $\leq 69$ & & & 0.008 & 0.30 & Fair or poor if age $\geq 72$ & & & 0.013 & 0.19 \\
\hline retired if $69<$ age $<72$ & & & 0.122 & 1.02 & & & & & \\
\hline retired if age $\geq 72$ & & & -0.051 & -0.48 & Alpha & 0.860 & 5.70 & 0.721 & 4.81 \\
\hline marital status & & & & & & & & & \\
\hline Single male if age $\leq 69$ & & & 0.360 & 11.02 & number of observations & 32,777 & & 32,777 & \\
\hline Single male if $69<$ age $<72$ & & & 0.066 & 0.60 & RMSE & 10.1208 & & 9.4233 & \\
\hline Single male if age $\geq 72$ & & & 0.400 & 5.98 & & & & & \\
\hline Married if age $\leq 69$ & & & 0.512 & 12.53 & & & & & \\
\hline Married if $69<$ age $<72$ & & & 0.389 & 2.87 & & & & & \\
\hline Married if age $\geq 72$ & & & 0.482 & 6.17 & & & & & \\
\hline income sources (in 10,000s) & & & & & & & & & \\
\hline Earned income if age $\leq 69$ & & & 0.020 & 14.79 & & & & & \\
\hline Earned income if $69<$ age $<72$ & & & -0.005 & -0.31 & & & & & \\
\hline Earned income if age $\geq 72$ & & & 0.018 & 2.95 & & & & & \\
\hline Annuity income if age $\leq 69$ & & & 0.069 & 9.46 & & & & & \\
\hline Annuity income if $69<$ age $<72$ & & & 0.077 & 4.31 & & & & & \\
\hline Annuity income if age $\geq 72$ & & & 0.048 & 3.64 & & & & & \\
\hline wealth (in 10,000's) & & & & & & & & & \\
\hline Housing wealth if age $\leq 69$ & & & 0.011 & 17.46 & & & & & \\
\hline Housing wealth if $69<$ age $<72$ & & & 0.012 & 6.54 & & & & & \\
\hline Housing wealth if age $\geq 72$ & & & 0.012 & 8.48 & & & & & \\
\hline Nonhousing wealth if age $\leq 69$ & & & 0.000 & 7.41 & & & & & \\
\hline Nonhousing wealth if $69<$ age $<72$ & & & 0.001 & 6.24 & & & & & \\
\hline Nonhousing wealth if age $\geq 72$ & & & 0.000 & 6.27 & & & & & \\
\hline
\end{tabular}

We can use the estimated age and cohort estimates from the first column of Table 2-1 to predict PRA balances for any cohort at any age. These are shown in Figure 2-2. For example, households that attained age 63 in 2003, which were therefore members of the C57 cohort (they were 57 in 1997), are predicted to hold PRA assets of $\$ 98,869$ at age 63 , while households that attained age 63 six year earlier in 
1997 are predicted to hold PRA assets of only $\$ 80,505$ - a 23 percent difference. Figure 2-2 also shows 95 percent confidence bands for these two predictions.

\section{F 2-2. Predicted PRA balance for households with a PRA, using estimates from exponential model (NLLS), with confidence intervals}

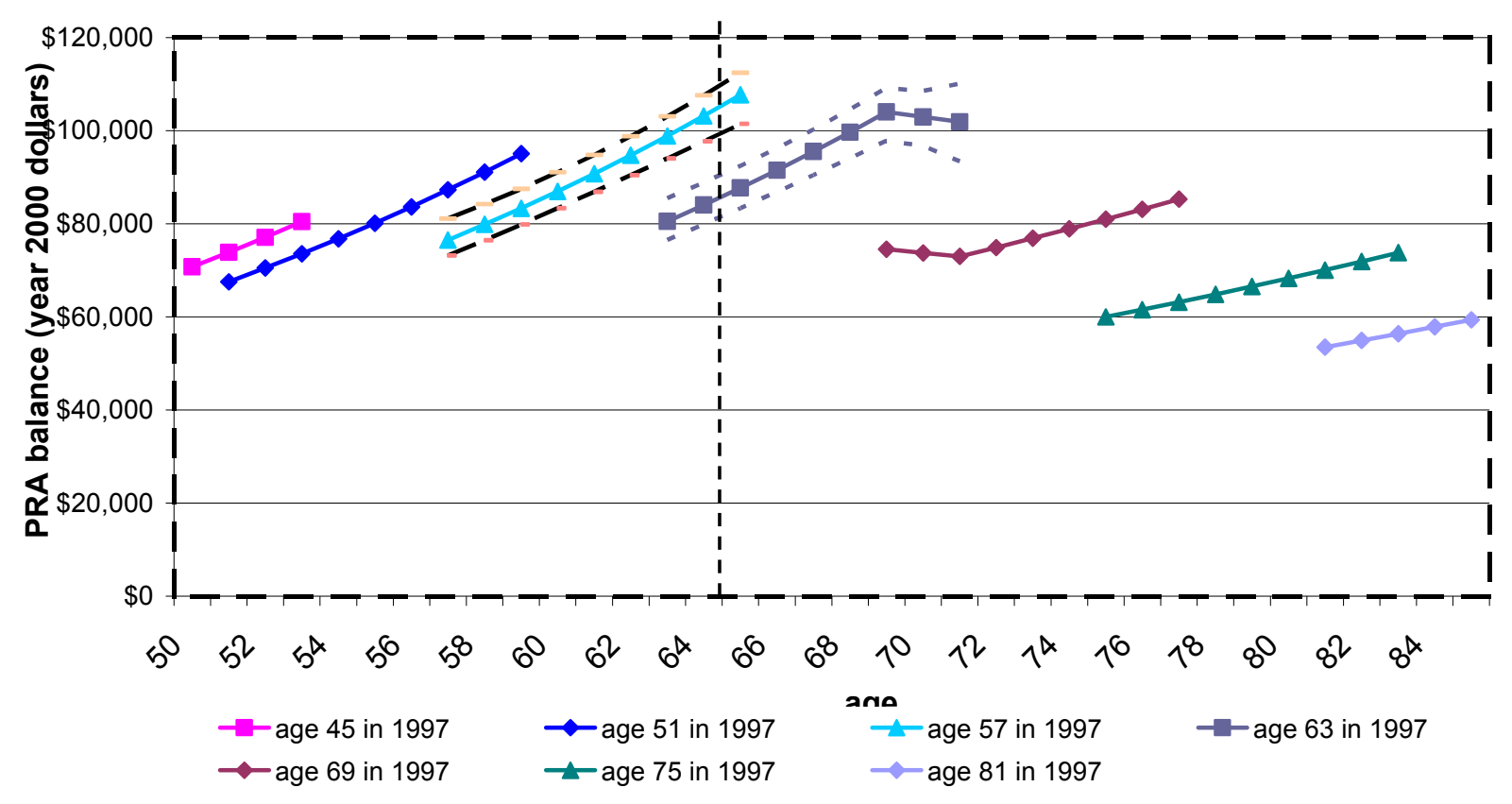

The estimates in the second column of Table 2-1 describe the relationship between PRA balances and household attributes. We use the same set of household attributes as in the foregoing estimates, but we now interact each household attribute with three age segments: less than age 69, age 69 to 71, and greater than age 71. The marginal estimates, like those for the probability of having a PRA, show that average balances are higher for those who are married, have greater earned income or annuity income, have greater housing wealth and greater non-housing wealth, and are in better health. Among households under the age of 69, married men have 36 percent more in PRA assets than single females (the omitted group) and married households have 51 percent more in PRA assets than single females. An additional $\$ 10,000$ in earned income is associated with 2 percent more in PRA assets, and an additional $\$ 10,000$ in annuity income is associated with a 6.9 percent increase in PRA wealth. An additional $\$ 10,000$ in housing wealth is associated with a 1.1 percent increase in PRA assets; an additional $\$ 10,000$ in non-housing wealth with an increase of 0.03 percentage points (rounded to zero in Table 2-1) in PRA assets. Single persons in very good or excellent heath have 36 percent more in PRA assets than single persons in fair or poor health. This difference is 32 percent for married men and 18 percent for married women.

Table 2-2 illustrates the combined impact of different sets of household attributes on PRA balances, using the same approach that we applied in the previous 
section. We again consider households between the ages of 60 and 63 , and use the same "lowpercentile" and "high-percentile" sets of attributes as above. The first column of Table 2-2 shows the predicted PRA balance for a household with low income, low wealth, and poor health. The next column shows the balance for a household with high income, high wealth, and good health. For households in the 60 to 63 age range who are not retired, the predicted balance for households in the lowpercentile group is $\$ 45,984$, compared to $\$ 134,167$ for those in the highpercentile group. For households in this age group who are retired, the values are $\$ 46,281$ and $\$ 139,182$, respectively.
Table 2-2. Estimated PRA balance, for selected attributes.

\begin{tabular}{|c|c|c|}
\hline \multirow{2}{*}{$\begin{array}{c}\text { Attributes and } \\
\text { balance }\end{array}$} & \multicolumn{2}{|c|}{ Age } \\
\hline & 60 to 63 & 60 to 63 \\
\hline & \multicolumn{2}{|c|}{ Not retired } \\
\hline Marital status & Single Male. & Married \\
\hline Earned income & 10th pctile & 90th pctile \\
\hline Annuity income & 0 & 0 \\
\hline Housing wealth & 10th pctile & 90th pctile \\
\hline Nonhousing wealth & 10th pctile & 90th pctile \\
\hline Health & Fair-Poor & Ex-VG \\
\hline \multirow[t]{2}{*}{ PRA balance } & $\$ 45,894$ & $\$ 134,167$ \\
\hline & \multicolumn{2}{|c|}{ Retired } \\
\hline Marital status & Single Male. & Married \\
\hline Earned income & 0 & 0 \\
\hline Annuity income & 10th pctile & 90th pctile \\
\hline Housing wealth & 10th pctile & 90th pctile \\
\hline Nonhousing wealth & 10th pctile & 90th pctile \\
\hline Health & Fair-Poor & Ex-VG \\
\hline PRA balance & $\$ 46,281$ & $\$ 139,182$ \\
\hline
\end{tabular}

\section{The Probability of a PRA Withdrawal}

Having set the stage with analysis of the ownership of PRAs and average ageand cohort-specific balances, we now examine data on PRA withdrawals. We begin by using data from the SIPP to calculate withdrawals from all personal retirement accounts as a proportion of balances. Respondents are asked to provide the amount received from a draw on an IRA, Keogh, 401(k) or Thrift Plan in each month during the 1997 to 2005 period. Recall that they are also asked to provide balances in these various accounts at seven different points in time between 1997 and 2005. We calculate the annual withdrawal rate as the sum of all withdrawals during the twelve months following a month in which the balance is reported, divided by the reported balance. In this section we examine the probability of any withdrawal during a twelve month period, and in the next we analyze withdrawals as a percentage of the PRA balance.

Figure 3-1 combines data from all of the SIPP cohorts and shows the agespecific probability of a withdrawal from a PRA. These are the vertical bars in the figure. The entry for each age combines data from several cohorts, so it pools information from households who were that age in different years. As we will show below, the cohort effects are negligible for this series. The percentage of households making a withdrawal grows slowly from about 10 at age 60 to about 23 at age 69 . Between the ages of 69 and 71, however, it jumps to over 60, and it fluctuates around 70 for households over the age of 73 . Overall, Figure 3-1 suggests that at ages prior to 
$701 / 2$, most households with PRAs are not making withdrawals. The probability of making a withdrawal only exceeds fifty percent after age $701 / 2$, and even then, is well below one hundred percent.

One of the most surprising features of Figure 3-1 is that the withdrawal rate is well below 100 percent following the age at which RMDs commence. In part, this is because holders of Roth IRAs (and holders of Keoghs if they are still working) are not subject to required minimum distributions, which apply to traditional IRAs and to rollover IRAs. Among households age 72 to 85 in the SIPP, the withdrawal rate for households with zero earnings is 8 percentage points higher than the rate for households with earnings. An 2010 Investment Company Institute report by Holden and Schrass (2010b) reports that 28.9 percent of all IRAs are Roth IRAs and 40.1 percent of households with an IRA have a Roth IRA (many households have multiple IRAs). A recent EBRI study by Copeland (2009), based on data from the 2007 Survey of Consumer Finances, reports that that 31.7 percent of households with an IRA have at least one Roth IRA. Because Roth IRAs are a relatively recent phenomenon, the fraction of elderly households owning Roth IRAs is likely to be lower than the fraction of all households owning Roth IRAs, but is nonetheless likely to be substantial.

Another explanation of the withdrawal probability below 100 percent for households over the age of $701 / 2$ is that in married couples, the owner of the PRA may be the wife, and she may be younger than the husband, whose age was used to determine the household's "age." If the wife is not yet $701 / 2$, she is not required to make a distribution from her PRA.

Other data sources also show withdrawal rates well under 100 percent for households older than the RMD age. The Investment Company Institute's IRA Owners Survey, which is summarized in Holden and Schrass (2010a), finds that only 73 percent of households aged 70 or older with a traditional IRA made a withdrawal in 2008, 70 percent in 2009 and 53 percent in 2010 (the RMD was suspended in tax year 2010). Tabulations of IRS data on IRAs compiled by Bryant and Sailer (2006) show that 82.6 percent of households headed by someone between the ages of 70 to 75 , 81.7 percent of those headed by someone between the ages of 75 and 80 , and only 61.8 percent of households headed by someone over the age of 80 made distributions in tax year 2001. Unpublished tablulations from the Survey of Consumer Finances by the Investment Company Institute suggest somewhat higher rates of withdrawal amongst households over the age of 70 . The estimates from the 2007 SCF appear to be approximately 82 percent.

Another possible explanation for the low withdrawal rate is that survey respondents were confused by or misinterpreted the survey question. ${ }^{3}$ They were

\footnotetext{
${ }^{3}$ Low withdrawal rates appear to be a problem with all household surveys. Sabelhaus and Schrass (2009) compare aggregate from the Current Population Survey, the Survey of Consumer Finance and the ICI Tracking/IRA Survey with IRA distributions reported to the Internal Revenue Service. They find that the household surveys substantially underestimate withdrawals.
} 
asked if they "... receive income from a draw on an IRA/Keogh/401k or Thrift Plan in this month?" Some respondents who withdrew funds from an IRA or 401(k) may simply have transferred the funds to a taxable account with the same financial institution, and they may not have considered this transaction one that gave them income from their PRA. Holden and Schrass (2010b) report that about 30 percent of households (of all ages) making an IRA withdrawal indicate that they "reinvested or saved it in another account." At some institutions, the transfer of funds in conjunction with RMD requirements may even be automatic; this may increase the likelihood of household mis-reporting.

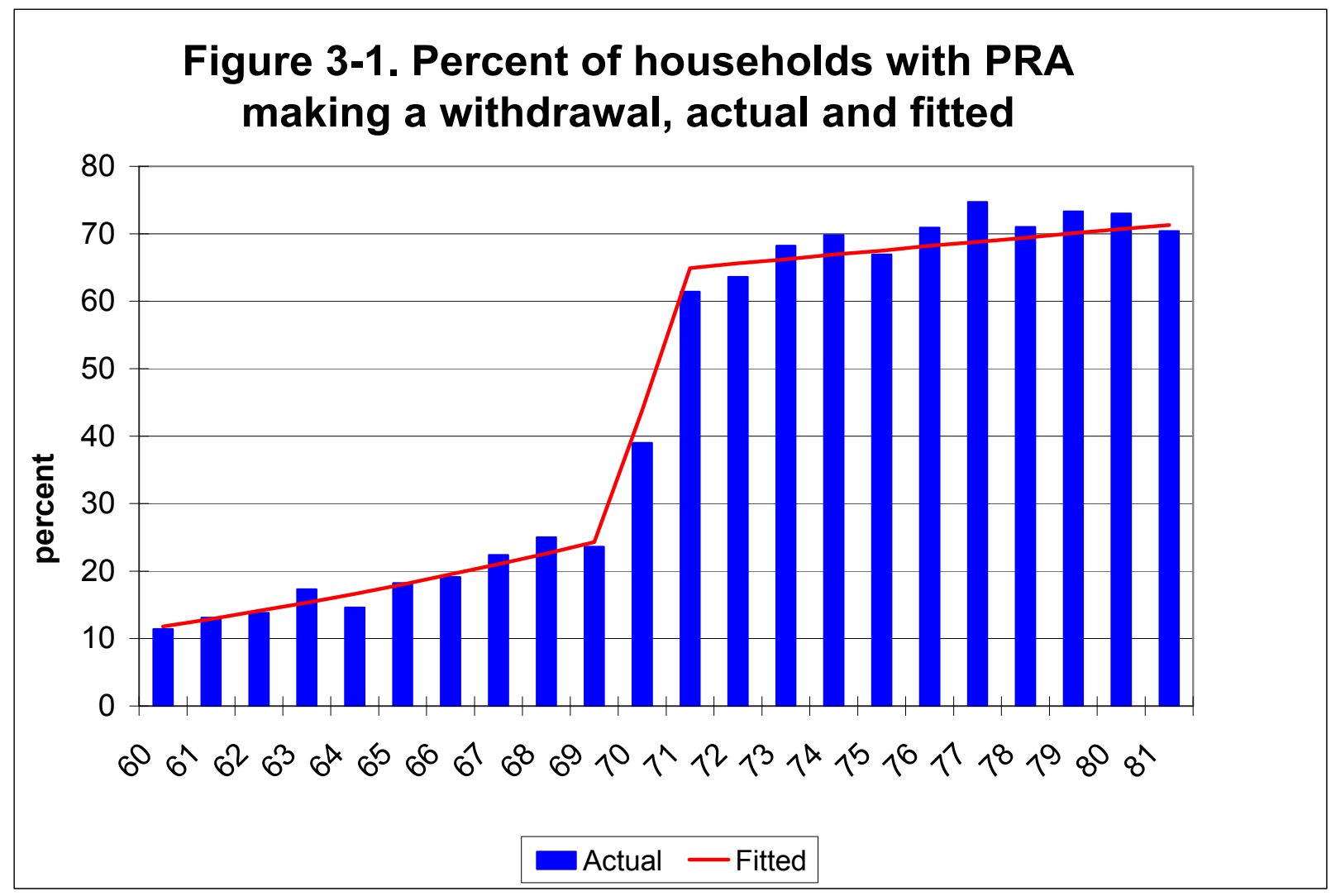

The low rate of PRA withdrawal observed in the SIPP, in data collected by the $\mathrm{ICI}$, and in IRS data is also observed in the HRS. Figure 3-2 shows withdrawals based on HRS as well as SIPP data for 2004. There are two key differences between these estimated withdrawal rates. First, the HRS data pertain to withdrawals over a two year period, while the SIPP data describe withdrawals over a one-year span. This creates a presumption for the HRS withdrawal rates to exceed the SIPP withdrawal rates. Second, the HRS only contains complete information on balances in IRA and Keogh plans, while the SIPP data include all 401(k) and 401(k)-like plans, thrift saving plans, IRAs and Keogh accounts. At retirement, many 401(k) balances are rolled over into an IRA and thus the IRA balances in the HRS may include assets that were originally accumulated in $401(\mathrm{k})$ accounts. In spite of the differences in the two data sources, the 
results in Figure 3-2 suggest remarkable agreement with respect to withdrawal behavior. Both surveys suggest that many households only begin to withdraw funds when forced to do so at the RMD age. Both surveys show that the overall withdrawal rate is well under 100 percent following the RMD age. In addition, the similarity of the HRS and SIPP withdrawal probabilities for households in their 60s suggests that the households making withdrawals in one year often make withdrawals in the next year as well. If this were not the case, the HRS withdrawal rate, based on two years of data, could be as much as twice the SIPP withdrawal rate based on a single year of data.

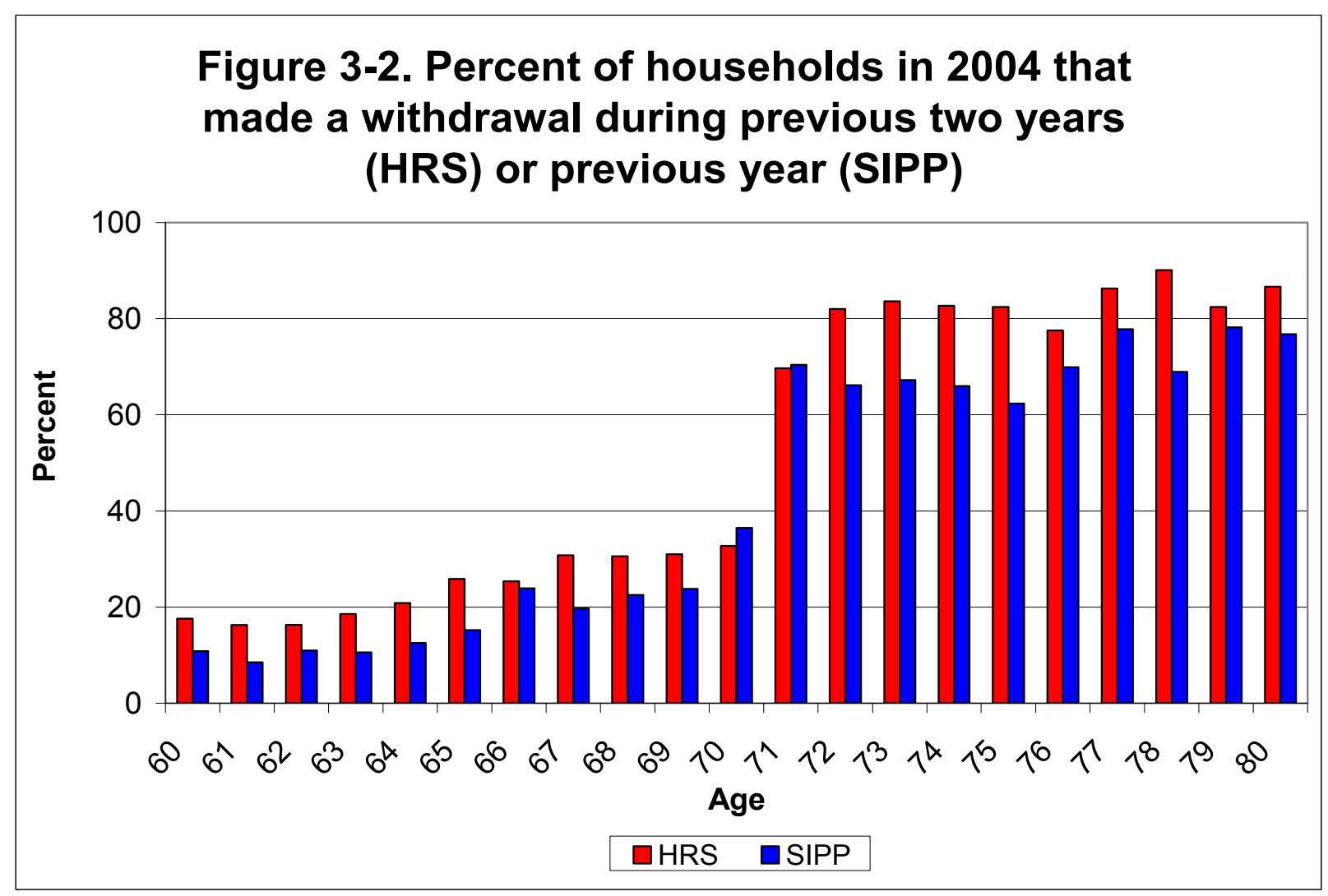

To describe the relationship between household attributes and the likelihood that a household makes a withdrawal, we use the SIPP data to estimate a probit model for whether the household makes a withdrawal using the same set of explanatory variables that we considered in our earlier data analysis. The results, which are reported in Table 3-1, show the marginal relationship between household attributes and the probability of making a withdrawal for households with a PRA. This table has three columns. The first shows estimates of the relationship between the withdrawal probability and age, with age specified as a piecewise linear function with three segments-60 to 69,70 to 71 , and 72 to 85 . The estimation sample includes all households age 60 to 85 . The estimates in column 1 are used to estimate the relationship between age and the probability of withdrawal and the predictions based on these estimates are overlayed on the actual data on age-specific withdrawal rates in Figure 3-1; this is the "fitted" line in that figure. 
The estimates show that the probability of withdrawal increases by 0.020 per year of age (with z-score of 9.94) for households younger than age 69, by 0.199 (zscore of 25.94) between ages of 69 and 71 , and by 0.007 per year of age (z-score of 4.07) for households over the age of 71 . The large estimate of the effect of passage through the age at which RMDs are first required suggests that many households are postponing distributions until they reach age $701 / 2$.

The second column of Table 3-1 shows estimated age and cohort effects. The cohort effects are small and the age effects change little when the cohort effects are added. This finding supports our use of pooled data from all cohorts in constructing Figure 3-1. The estimates in the third column of Table 3-1 add all of the additional household attributes to the specification. Only a few of the household attributes are significantly related to the probability of withdrawal. For all age groups, persons with $\$ 10,000$ or more in PRA balances are about 0.7 percent more likely to make a withdrawal. For the under age 69 group, retired households are 14 percent more likely to withdraw. Households with earned income in all age groups are less likely to withdraw assets from their PRAs. The probability of making a withdrawal declines between two and three percentage points for each $\$ 10,000$ increase in earned income. Finally, for households under the age of 69 , single persons in poor health are about 13 percent more likely to make a withdrawal than single persons in very good or excellent health.

We compute the predicted probability of a withdrawal using our "high percentile" and "low percentile" attributes as in the previous sections; the results are shown in Table 3-2. The probit models in Table 3-1 include the PRA balance as an additional covariate that was not included in the probit models of PRA ownership or the nonlinear models for PRA balances. We consequently hold the PRA balance constant at its sample mean for both the high- and low-percentile households in Table 3-2. We include annuity income, as well as housing and non-housing wealth, in the set of household attributes that we consider even though the estimated effects of these variables are typically not significantly different from zero in our probit models. To highlight the effect of the PRA balance, Table 3-2 also includes two additional panels at the bottom of the Table showing the relationship between the PRA balance and the withdrawal probability. These panels show averages for the bottom and top quintiles of the distribution of PRA assets. Thus the top panels of this table show the effect of households attributes on the probability of withdrawal, holding the PRA balance constant. The bottom panel adds the effect of the PRA balance on the probability of withdrawal, allowing it to vary in the same "percentile" fashion as the other household attributes. 


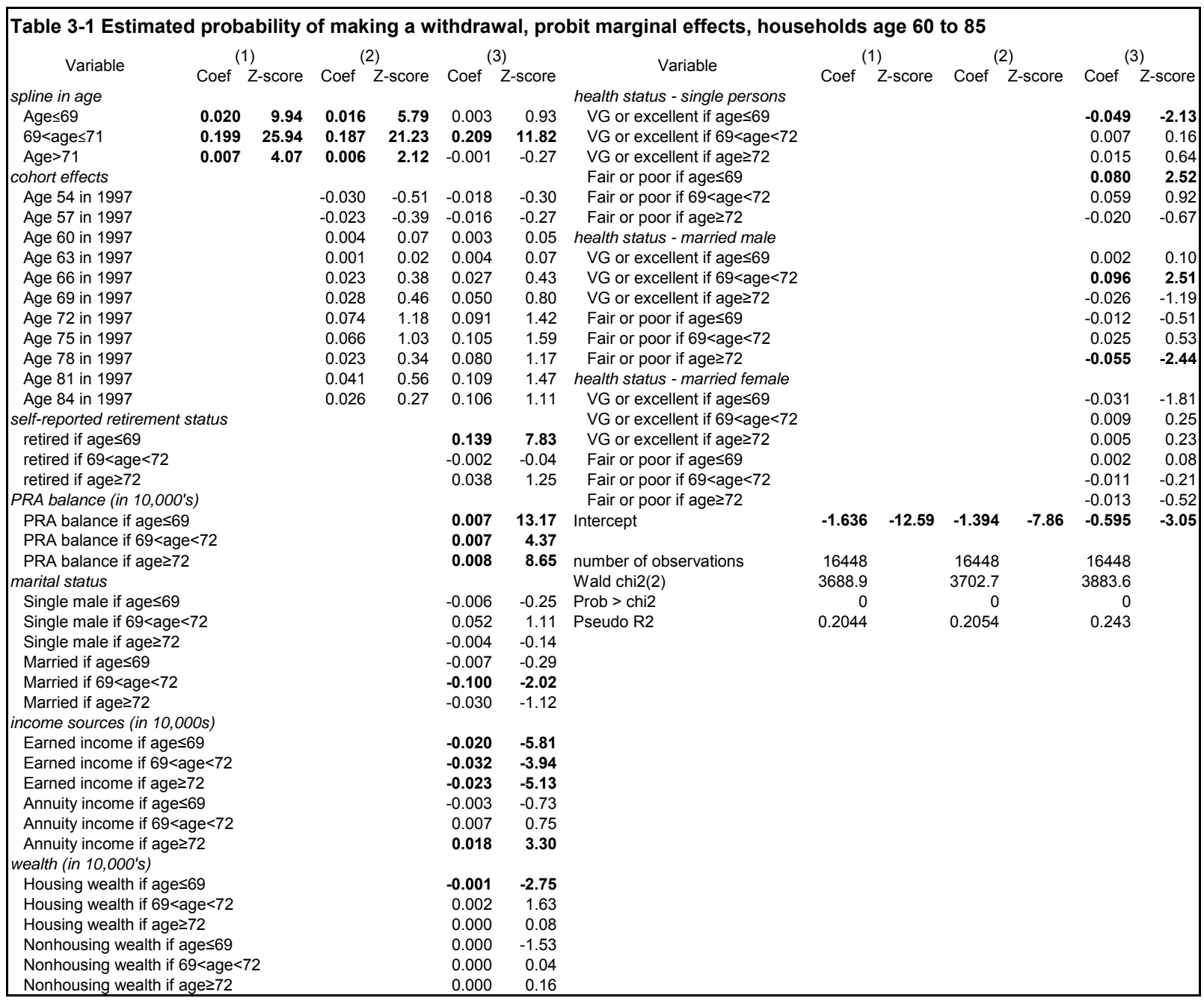

The results in Table 3-2 highlight two conclusions. First, households with PRA assets in the top quintile are much more likely than households in the bottom quintle to withdraw assets from their PRA. This is true regardless of whether the household is retired, and regardless of the household's age. For both age groups and for retirees as well as non-retirees the difference in PRA assets between the top and bottom quintiles is striking. The average PRA balance is typically about $\$ 5,000$ in the lowest quintile and over $\$ 250,000$ in the top quintile. The respondent-reported withdrawal rate for older households in the bottom quintile of PRA holdings is extremely low -31.3 percent - and remains a puzzle.

Second, the top two panels show that, holding PRA assets constant, the difference between the withdrawal rates of the low- and high-percentile attribute households depends on age and retirement status. For households in the younger age range who are not retired the estimated withdrawal probability for the $10^{\text {th }}$ percentile group is over four times as high as that for the $90^{\text {th }}$ percentile group $(0.229$ versus $0.050)$. For retired household in this age range the difference is also large but the rates are higher for both attribute groups -0.360 versus 0.198 . That is, holding PRA assets constant, households who have very limited assets outside their PRA and are in poor 
health are more likely to draw on PRA assets before the age at which distributions are required than households who are in good health and who have substantial levels of non-PRA assets. For older households, however, there is little difference between the withdrawal rates of the low- and high-percentile group- 0.637 versus 0.574 for households that are not retired and 0.694 versus 0.729 for retired households. Not surprisingly, once households are required to make distributions, the differences in withdrawal probabilities that appear to be related to household attributes are moderated.

Table 3-2. Estimated probability of making a withdrawal, for selected attributes.

\begin{tabular}{|c|c|c|c|c|}
\hline \multirow{2}{*}{$\begin{array}{l}\text { Attributes and predicted } \\
\text { probability }\end{array}$} & \multicolumn{4}{|c|}{ Age } \\
\hline & $60-69$ & $60-69$ & $72-85$ & $72-85$ \\
\hline & \multicolumn{4}{|c|}{ Not retired } \\
\hline $\begin{array}{l}\text { Marital status } \\
\text { PRA balance }\end{array}$ & $\begin{array}{l}\text { Single Male. } \\
\text { mean }\end{array}$ & $\begin{array}{l}\text { Married } \\
\text { mean }\end{array}$ & $\begin{array}{l}\text { Single Male } \\
\text { mean }\end{array}$ & $\begin{array}{c}\text { Married } \\
\text { mean }\end{array}$ \\
\hline Earned income & 10th pctile & 90th pctile & 10th pctile & 90th pctile \\
\hline Annuity income & 0 & 0 & 0 & 0 \\
\hline Housing wealth & 10th pctile & 90th pctile & 10th pctile & 90th pctile \\
\hline Nonhousing wealth & 10th pctile & 90th pctile & 10th pctile & 90th pctile \\
\hline Health & Fair-Poor & Ex-VG & Fair-Poor & Ex-VG \\
\hline \multirow[t]{2}{*}{ Probability } & 0.229 & 0.050 & 0.637 & 0.574 \\
\hline & \multicolumn{4}{|c|}{ Retired } \\
\hline Marital status & Single Male & Married & Single Male & Married \\
\hline PRA balance & mean & mean & mean & mean \\
\hline Earned income & 0 & 0 & 0 & 0 \\
\hline Annuity income & 10th pctile & 90th pctile & 10th pctile & 90th pctile \\
\hline Housing wealth & 10th pctile & 90th pctile & 10th pctile & 90th pctile \\
\hline Nonhousing wealth & 10th pctile & 90th pctile & 10th pctile & 90th pctile \\
\hline Health & Fair-Poor & Ex-VG & Fair-Poor & Ex-VG \\
\hline Probability & 0.360 & 0.198 & 0.694 & 0.729 \\
\hline \multicolumn{5}{|l|}{ Actual means by PRA quintile } \\
\hline & \multicolumn{4}{|c|}{ Not retired } \\
\hline PRA balance quintile & Bottom quintile & Top quintile & Bottom quintile & Top quintile \\
\hline PRA balance & $\$ 4,422$ & $\$ 266,319$ & $\$ 3,935$ & $\$ 283,313$ \\
\hline \multirow[t]{2}{*}{ Probability } & 0.055 & 0.099 & 0.313 & 0.733 \\
\hline & \multicolumn{4}{|c|}{ Retired } \\
\hline PRA balance quintile & Bottom quintile & Top quintile & Bottom quintile & Top quintile \\
\hline PRA balance & $\$ 5,967$ & $\$ 281,029$ & $\$ 5,419$ & $\$ 226,693$ \\
\hline Probability & 0.105 & 0.342 & 0.543 & 0.771 \\
\hline
\end{tabular}




\section{PRA Withdrawal Percentages}

Much of the interest in the pattern of withdrawals from PRAs arises from concern that households will draw down their retirement account balances either before retirement, or early in their retirement years, and then reach their later retirement years with very limited resources. To address this concern, the share of assets that are withdrawn from PRAs by those who make withdrawals is the natural measure to examine. The findings of the last section, which suggest that many households with PRAs do not begin to make withdrawals from these accounts until they reach the age at which minimum distributions are required, suggest that at least a substantial share of households with PRAs are maintaining or growing their PRA balances through the early years of retirement.

Figure 4-1 shows the percent of total PRA balances withdrawn by age for all PRA account holders in our SIPP sample. This figure, like Figure 3-1, pools data from the years 1997, 1998, 1999, 2001, 2002, 2004, and 2005. This figure shows the rate at which PRA assets are being withdrawn from the retirement saving system. The percent of balances withdrawn is calculated as the ratio of average withdrawals to the average initial asset balance. It is equivalent to the sum of withdrawals made by all households divided by the sum of initial balances. Before age 70 , the overall rate of withdrawal averages about 1.9 percent per year. In most years, the average real rate of return earned on PRA balances would exceed this value, so the pool of PRA assets would grow even in the absence of new contributions. Even after age 70, the average withdrawal rate is 5.2 percent. Over many historical periods, this rate would also fall below the average real return on assets held in PRAs. Since the period we examine, 1997 until 2005, is a period of relatively favorable asset market returns, our estimated withdrawal rates are consistent with the findings in Figure 1-1 of rising real PRA balances even after the age at which required minimum distributions begin.

Figure 4-2 compares the PRA withdrawal rate based on SIPP data for 2004 with that based on HRS data for 2004. This is the most recent year for which data from both surveys is available. Recall that the SIPP data include withdrawals from 401(k), 403(b), thrift plans, IRAs and Keoghs, but the HRS data only include withdrawals from IRAs and Keoghs, and that HRS withdrawals span a two-year period while SIPP withdrawals correspond to a single year. To make the HRS and SIPP withdrawals consistent, we have divided HRS withdrawals by two to create an estimate of the annual withdrawal rate. The two series show a similar pattern, although the withdrawal rate in the HRS is higher before age 70 than that in the SIPP -2.3 versus 1.5 percent. After age 70 , the average withdrawal rates in the two surveys are very similar; both are roughly equal to 5.1 percent. This figure suggests that the key conclusion from the two data sets for 2004 is similar to that from the SIPP data for all years in Figure 4-1. 

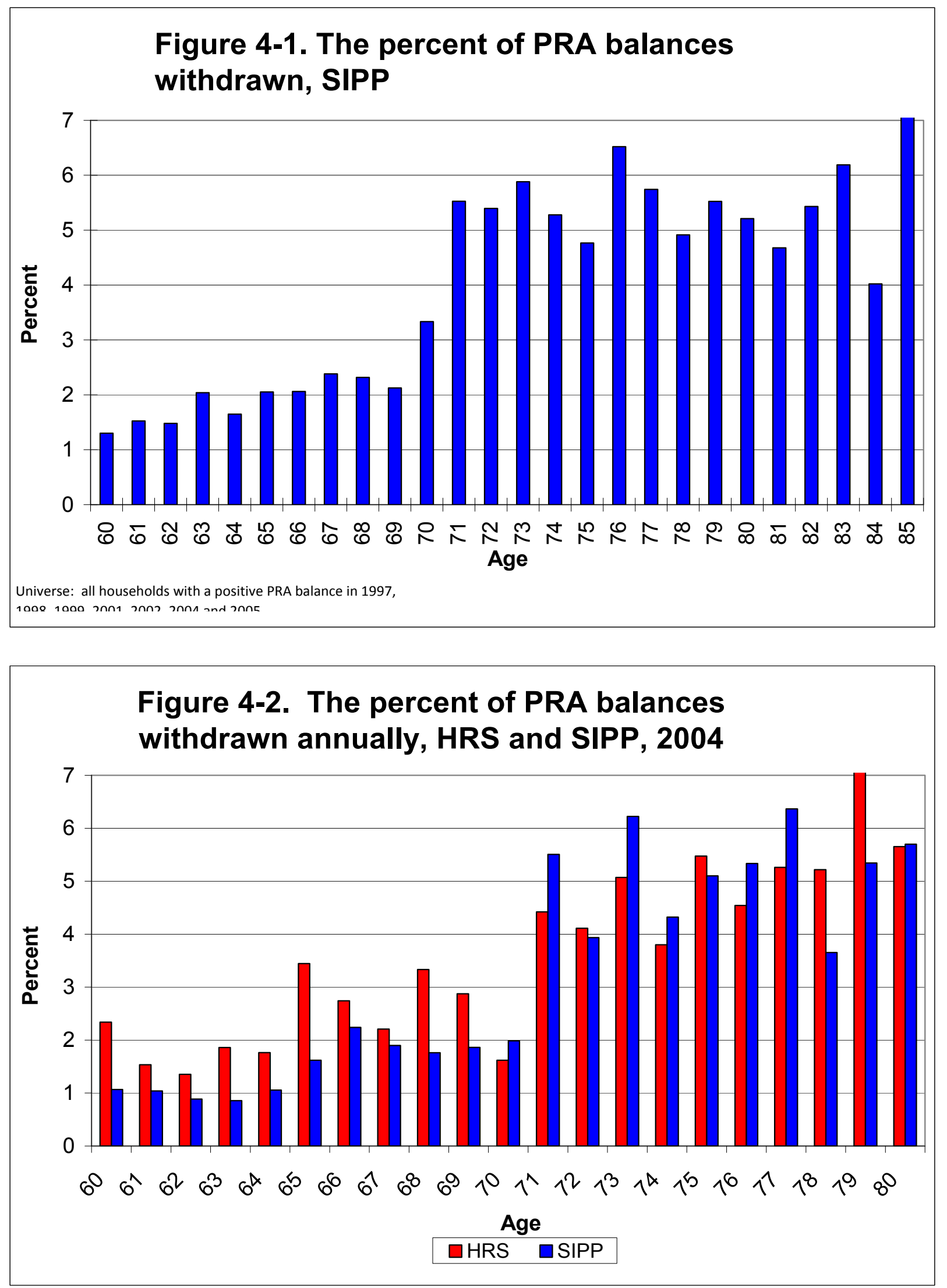
The data in Figures 4-1 and 4-2 describe aggregate withdrawal rates from the PRA system, but they do not indicate the withdrawal rate among households making a withdrawal. Particularly before age $701 / 2$, these two withdrawal rates can differ substantially. Figure 4-3 shows the average percentage of the PRA balance withdrawn for households making a withdrawal, calculated as the ratio of the average amount withdrawn to the average initial balance for the set of households making withdrawals. The average withdrawal conditional on a withdrawal averages 8.2 percent of the account balance for ages 60 to $69,7.3$ percent for ages 70 to 79 and 7.4 percent for ages 80 to 85 .

The owner of a traditional IRA or a 401(k) account must take a required minimum distribution (RMD) by April 1st of the year following the year in which he or she turns 70 and $1 / 2$. The RMD is obtained by dividing the account balance by an applicable distribution period taken from the Uniform Lifetime Table published by the IRS. For example, for an unmarried person age 72 or for a married person age 72 whose spouse is not more than 10 years younger, the distribution period was 25.6 years in 2006. Thus the required minimum distribution is $1 / 25.6=3.9$ percent of the IRA balance in that year. By age 80 the required minimum distribution is 5.3 percent and at age 90 it is 8.8 percent. These required minimum withdrawal rates are shown in Figure 4-3. It is clear that for households that make withdrawals, the average withdrawal after age $701 / 2$ exceeds the required RMD percentage. There is one age 85 - at which the average withdrawal falls below the RMD requirement, but this is likely to be an artifact of the small sample size at advanced ages.

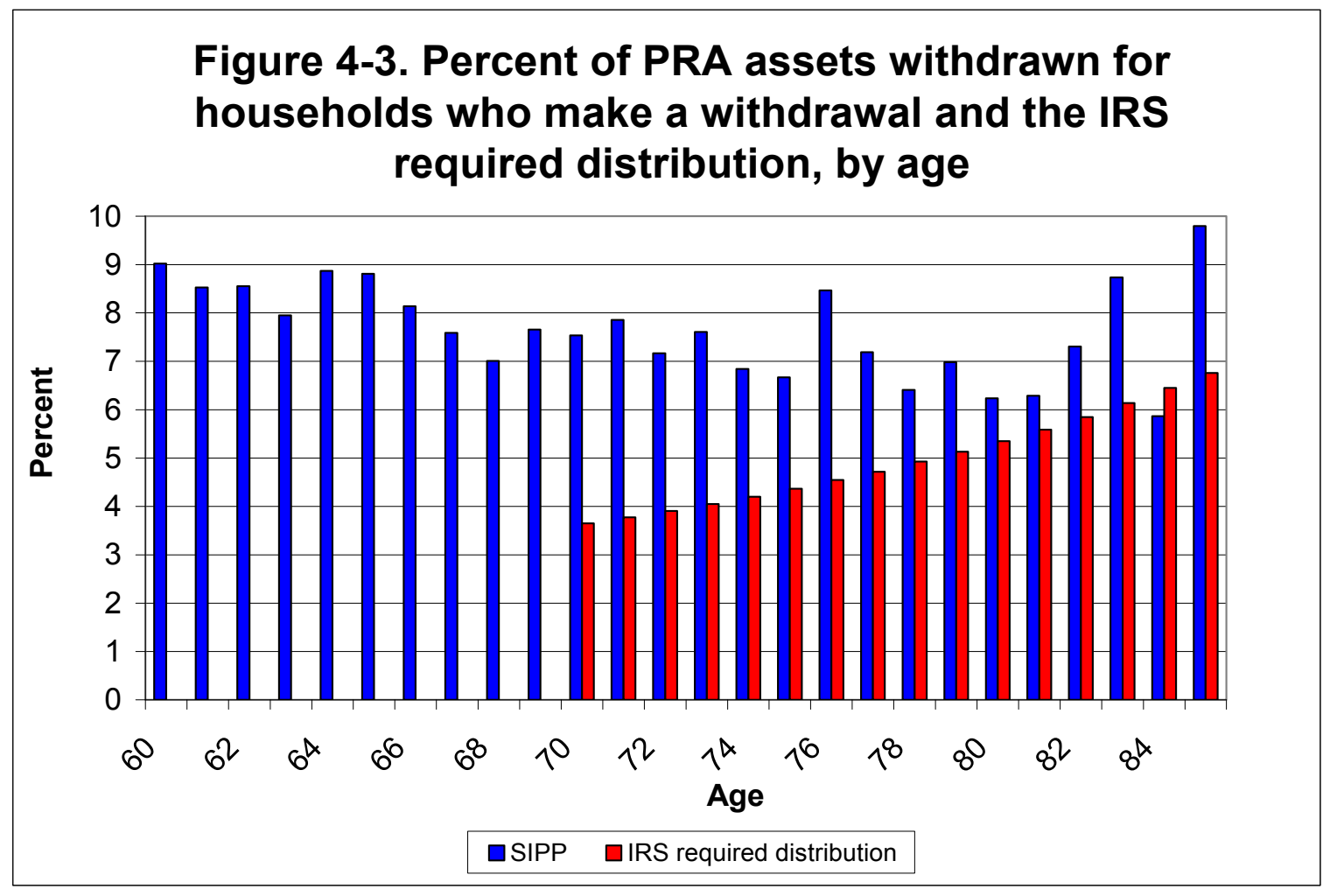


Figures 4-1 and 4-3 suggest that households that make a withdrawal take out substantially more, on average, than the age-specific average of total PRA funds withdrawn. We now consider the relationship between household attributes and the percent of the PRA balance withdrawn, conditional on a withdrawal. In particular, we emphasize the relationship between the PRA balance and the proportion withdrawn and the relationship between the age at withdrawal and the proportion withdrawn. We estimate the following model by nonlinear least squares:

$$
W_{i}=\left(Z_{i} \delta\right) B_{i}^{1+\sum \beta A G E c a t e g o r y}+\eta_{i}
$$

In this equation, $W$ represents assets withdrawn and $B$ represents the household's prewithdrawal PRA balance. This specification allows the fraction of assets withdrawn, $W_{i} / B_{i}$, to depend on $B_{i}$. The percentage of assets withdrawn is proportional to a linear function of household attributes, $Z_{i} \delta$, and the elasticity of the withdrawal rate with respect to the PRA balance depends on the household's age. The exponent on $B_{i}$ in (2), $1+\sum \beta A G E$ category, allows for different elasticities for households in different age categories. We consider four age categories: 60 to 69,70 to 71,72 to 75 , and 76 to 85. We estimate the relationship between the withdrawal rate and the PRA balance and household attributes by nonlinear least squares, using the specification in (2), rather than by a corresponding log-linear specification in the withdrawal rate because the model in (2) has a substantially better fit.

Table 4-1 reports estimates of the model described in (2). The first column shows results with only age and cohort indicator variables as explanatory variables in the set of $Z_{i}$ variables, and with age categories in the exponential term for $B_{i}$. The estimates in the second column expand the specification to include all of the other explanatory variables analyzed in previous sections as part of $Z_{\mathrm{i}}$. The results in the first column indicate that at a given age, households in older cohorts withdraw a larger proportion of their PRA balances conditional on making a withdrawal. The results in the second column suggest that few of the other household attributes have statistically significant effects on the withdrawal fraction. Earned income and annuity income are negatively related to the proportion withdrawn, but only three of the six estimated effects are statistically significant. Housing and non-housing wealth are positively related to the withdrawal proportion in all age intervals but the effects are only statistically significant for households over the age of 72 . Retirement status, marital status, and health status do not have statistically significant effects on the proportion of the PRA withdrawn. The elasticity of the withdrawal (W) with respect to the PRA balance is 0.55 in the 60 to 69 age range, 1.15 in the 70 to 71 range, 1.14 in the 72 to 75 range, and 1.18 in the 76 to 85 age range. 


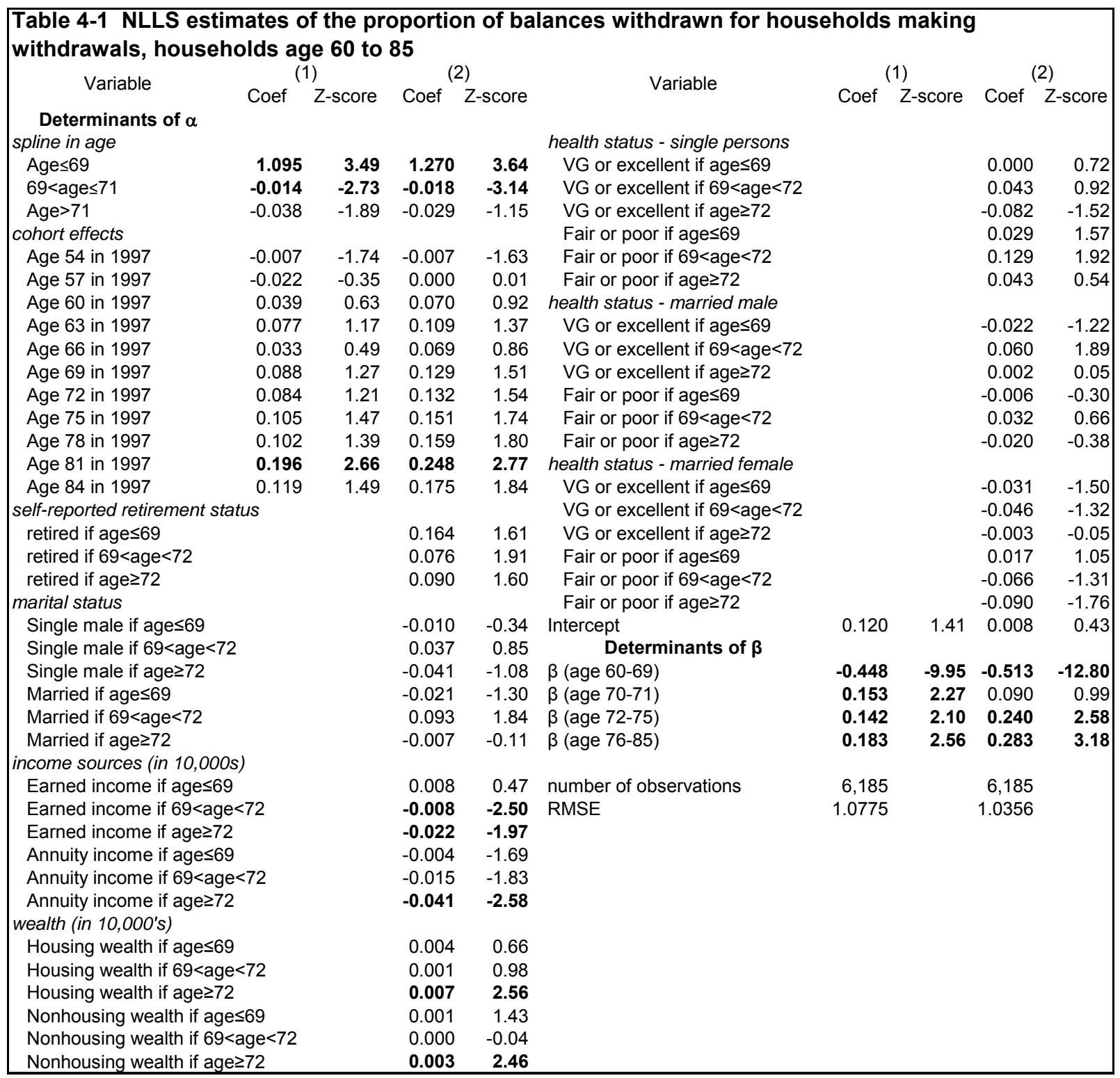

Table 4-2 reports the fitted value of the proportion of assets withdrawn (W/B) for households with selected attributes. The format is the same as that in Table 3-2, with the top panel showing the percent withdrawn for sets of household attributes conditional on an average account balance and the bottom panel showing the percent withdrawn for the top and bottom quintiles of the distribution of PRA assets. The table shows two estimates of the predicted proportion of assets withdrawn: the mean of the ratio of withdrawals $(\mathrm{W})$ to balances $(\mathrm{B})$, and the ratio of the mean amount withdrawn to the mean balance. ${ }^{4}$ For households in the younger age group, whether retired or not, the proportion withdrawn is slightly greater for those with low-percentile attributes. For the older age group, however, the proportion withdrawn is more than twice as great for those with the high-quintile attributes as for those with the low-quintile attributes. One

\footnotetext{
${ }^{4}$ The mean ratio is calculated using the predicted $\mathrm{W}$ and actual $\mathrm{B}$ for each household.
} 
potential explanation of this finding is that it is due to reporting differences rather than behavioral differences. It is possible that households with higher income and larger holdings of assets outside their tax-deferred PRAs are more aware of their PRA withdrawal activity, and consequently report this activity with higher probability.

The results in the bottom panel suggest that the PRA balance is a key determinant of the proportion of assets withdrawn. For households in the 60 to 69 age range the predicted proportion of assets withdrawn for those in the bottom quintile is about 30 percent, compared to about 6 percent for those in the top quintile. For households in the older age range, the predicted proportion of assets withdrawn is about 20 percent in the bottom quintile, and again about 6 percent in the top quintile.

\begin{tabular}{|c|c|c|c|c|}
\hline \multirow{2}{*}{$\begin{array}{l}\text { Attributes and predicted } \\
\text { proportion withdrawn (W/B) }\end{array}$} & \multicolumn{4}{|c|}{ Age } \\
\hline & $60-69$ & $60-69$ & $72-85$ & $72-85$ \\
\hline & \multicolumn{4}{|c|}{ Not retired } \\
\hline Marital status & Single Male. & Married & Single Male & Married \\
\hline Earned income & 10th pctile & 90th pctile & 10th pctile & 90th pctile \\
\hline Annuity income & 0 & 0 & 0 & 0 \\
\hline Housing wealth & 10th pctile & 90th pctile & 10th pctile & 90th pctile \\
\hline Nonhousing wealth & 10th pctile & 90th pctile & 10th pctile & 90th pctile \\
\hline Health & Fair-Poor & Ex-VG & Fair-Poor & Ex-VG \\
\hline Mean W/B & 0.178 & 0.148 & 0.048 & 0.119 \\
\hline \multirow[t]{2}{*}{ Ratio of mean W to mean $B$} & 0.092 & 0.076 & 0.033 & 0.083 \\
\hline & \multicolumn{4}{|c|}{ Retired } \\
\hline Marital status & Single Male & Married & Single Male & Married \\
\hline Earned income & 0 & 0 & 0 & 0 \\
\hline Annuity income & 10th pctile & 90th pctile & 10th pctile & 90th pctile \\
\hline Housing wealth & 10th pctile & 90th pctile & 10th pctile & 90th pctile \\
\hline Nonhousing wealth & 10th pctile & 90th pctile & 10th pctile & 90th pctile \\
\hline Health & Fair-Poor & Ex-VG & Fair-Poor & Ex-VG \\
\hline Mean W/B & 0.214 & 0.171 & 0.043 & 0.127 \\
\hline Ratio of mean W to mean B & 0.110 & 0.088 & 0.029 & 0.089 \\
\hline \multicolumn{5}{|l|}{ Actual means by PRA quintile } \\
\hline & \multicolumn{4}{|c|}{ Not retired } \\
\hline PRA balance $(B)$ quintile & Bottom quintile & Top quintile & Bottom quintile & Top quintile \\
\hline Mean W & $\$ 2,491$ & $\$ 13,940$ & $\$ 1,506$ & $\$ 18,753$ \\
\hline Mean B & $\$ 7,713$ & $\$ 284,056$ & $\$ 7,969$ & $\$ 353,581$ \\
\hline Mean(W/B) & 0.337 & 0.054 & 0.201 & 0.060 \\
\hline \multirow[t]{2}{*}{ Ratio of means } & 0.323 & 0.049 & 0.189 & 0.053 \\
\hline & \multicolumn{4}{|c|}{ Retired } \\
\hline PRA balance $(B)$ quintile & Bottom quintile & Top quintile & Bottom quintile & Top quintile \\
\hline Mean W & $\$ 4,080$ & $\$ 18,446$ & $\$ 1,482$ & $\$ 13,955$ \\
\hline Mean B & $\$ 14,010$ & $\$ 307,819$ & $\$ 7,124$ & $\$ 242,536$ \\
\hline Mean(W/B) & 0.329 & 0.064 & 0.231 & 0.058 \\
\hline Ratio of means & 0.291 & 0.060 & 0.208 & 0.058 \\
\hline
\end{tabular}


The results in Table 4-1 suggest that age is an important determinant of the percentage of the PRA balance withdrawn, and that the PRA balance itself is also an important influence on withdrawals. To explore the interaction of these two effects in detail, Figure 4-4 shows the average predicted and actual values of W/B for each $\$ 10,000$ interval of the distribution of PRA assets. The figure suggests two conclusions. First, the model fits the actual data on withdrawals reasonably well. Second, the withdrawal proportion increases very rapidly as PRA assets decline below $\$ 50,000$ going from less than five percent when the PRA balance is $\$ 250,000$ or greater, to about ten percent at a PRA balance of $\$ 50,000$, to over thirty percent at a PRA balance below $\$ 10,000$.

Figure 4-5 shows the relationship between the PRA balance and the predicted withdrawal proportion (W/B) for the 60 to 69 and the "72 and older" age groups. For households with PRA assets of $\$ 200,000$ or more, the percentage of assets withdrawn does not vary much with age for either age group. At lower PRA levels, however, there is a large difference as can be seen by the vertical distance between the two profiles at low levels of $\mathrm{B}$. For example, on average, households age 60 to 69 with PRA assets between $\$ 20,000$ and $\$ 30,000$ withdraw about 22 percent of their PRA assets each year. Households with the same level of PRA assets in the 72 and older age group average withdrawals equal to only 10 percent of their assets. To provide some context for this finding, households in the 60 to 69 age group are predicted to withdraw at least 10 percent of their assets until they have assets of $\$ 90,000$ or more.

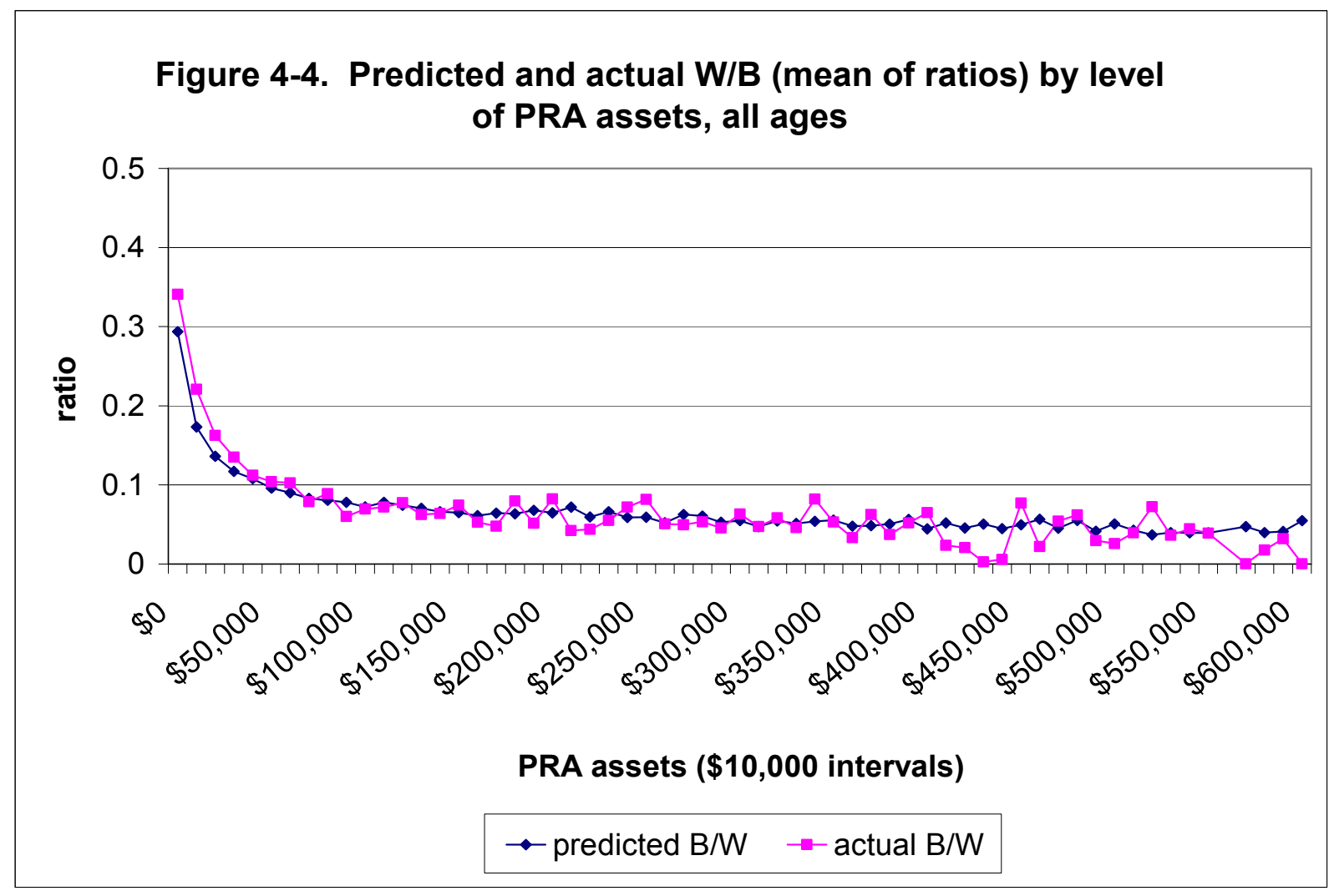




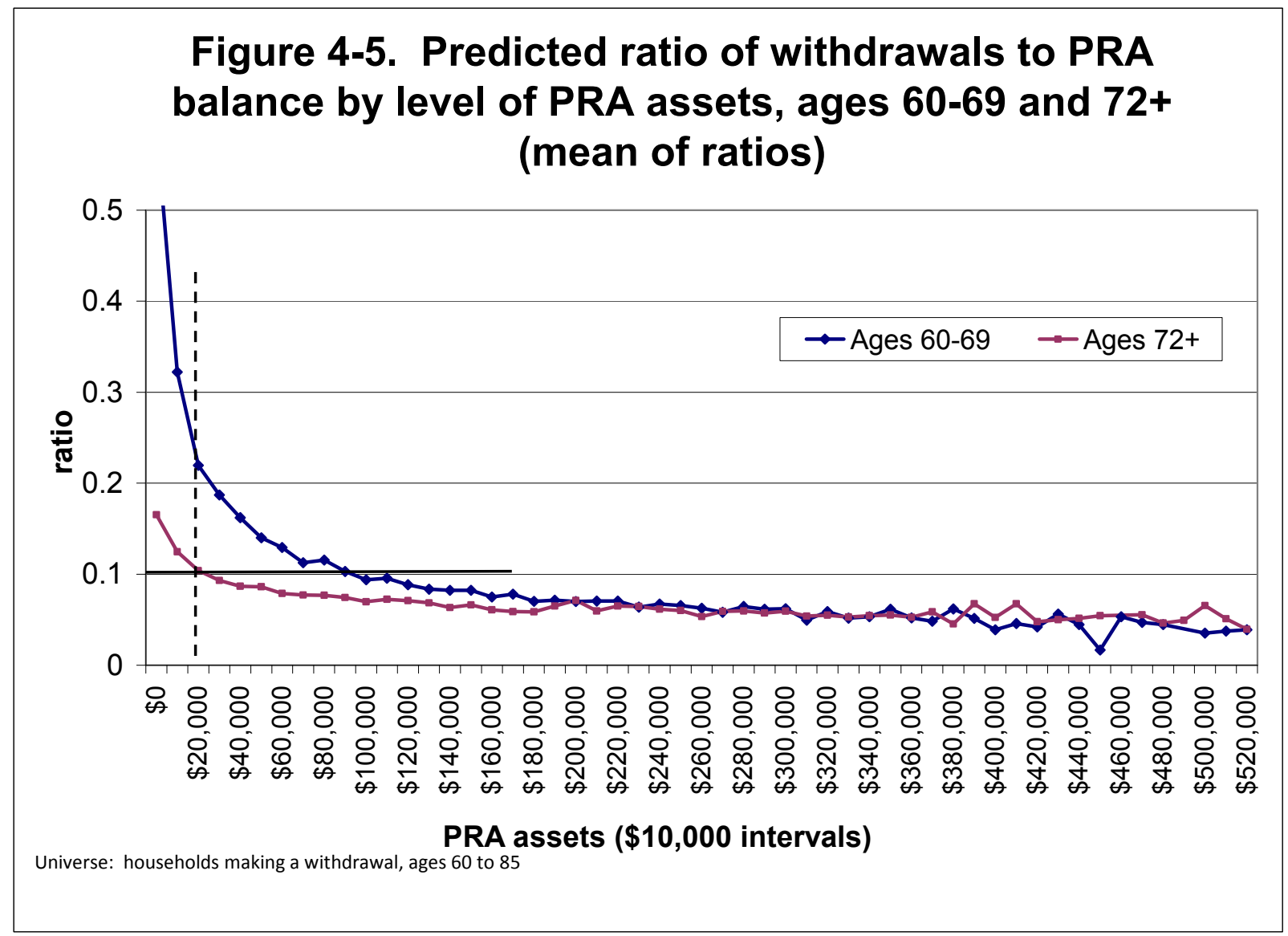

\section{Household Heterogeneity: The Distribution of Withdrawal Rates}

Our analysis so far has used simple probit models to describe how various factors affect the probability that a household withdraws assets from a PRA, and has demonstrated that a number of household attributes are correlated with withdrawal rates. We have not, however, characterized the heterogeneity in household withdrawal behavior. To do that, we need to characterize differences in both the probability of a withdrawal conditional on PRA ownership, as in Figure 3-1, and in the proportion of the PRA that is withdrawn, conditional on a withdrawal, as in Figure 4-1. Together, these two inputs determine the distribution across households of the proportion of PRA balances withdrawn - a distribution with many entries at zero for younger households. 


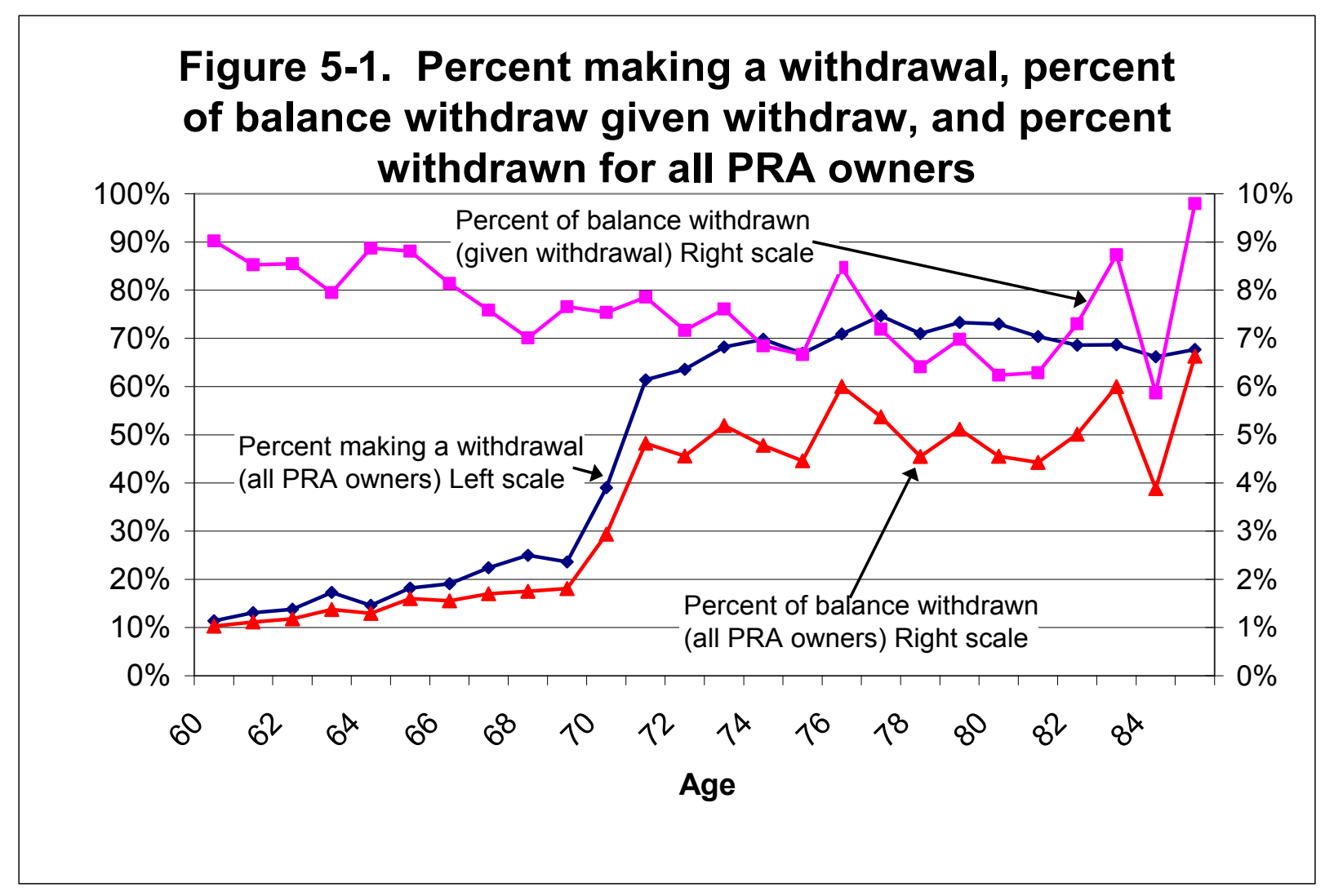

Before considering this distribution, we summarize the average patterns of withdrawals at different ages. Figure 5-1 pools data on households of various ages in all cohorts. It shows that the average percentage of households who own a PRA who make a withdrawal increases from 11.4 percent at age 60 to 23.6 percent by age 69 . This percentage jumps to over 60 percent by age 71 , when the age of the household head exceeds the age at which RMDs must begin. The percentage of assets withdrawn by households that make a withdrawal is about nine percent at age 60 . It declines to between seven and eight percent between ages 68 and 76, and, while it becomes somewhat more variable after that age, falls below seven percent at many ages in the late 70 s and early $80 \mathrm{~s}$. The average percentage of all PRA assets withdrawn, which is the product of the two foregoing series, is about one percent at age 60 . It rises to about 1.8 percent by age 69 , then jumps to about five percent by age 71 and fluctuates around that level through age 85 .

Figures 5-2 and 5-3 describe the heterogeneity in withdrawal percentages for households with heads between the ages of 60 to 69 , and over the age of 72 , respectively. Both figures show the distribution of households by the percentage of their PRA balance that they withdraw. For households aged 60 to 69, i.e. before the age at which required minimum distributions must begin, withdrawals of a large proportion of the PRA balance are rare. The vertical lines in Figure 5-2 indicate that about 83 percent of households make no withdrawals, and that 90 percent of households make an annual withdrawal of less than five percent from their PRA. Only seven percent of households withdraw more than ten percent of their PRA assets. 
Figure 5-3 shows that for households older than 71, after RMDs begin for the household head, most withdrawals are still modest. The percentage of households making large withdrawals from their PRAs is substantially greater for this group, however, than for the younger group. The vertical lines in Figure 5-3 indicate that 59 percent of households withdraw less than five percent of their PRA balances and 77 percent withdraw less than 10 percent. Nearly a quarter of the households in this older group, however, withdraw more than ten percent of their PRA, and 11 percent withdraw more than 20 percent. Our results from the previous section suggest that the households withdrawing large fractions of their PRA balances tend to have low balances. Some households may withdraw a large proportion of PRA assets because of special circumstances, such as illness of a spouse or entry into a nursing home. Understanding the correlates of large withdrawals is an important topic for future study.

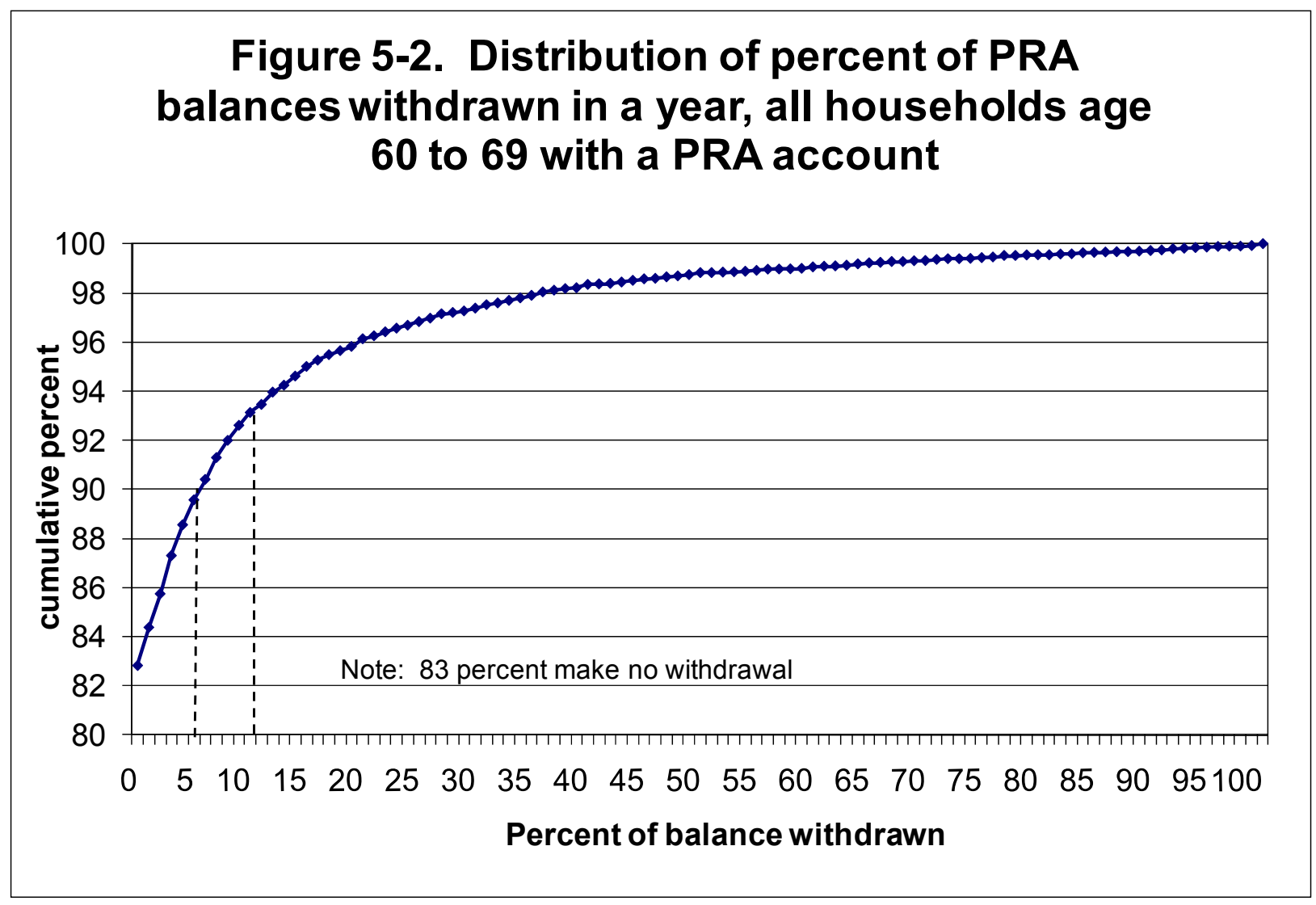




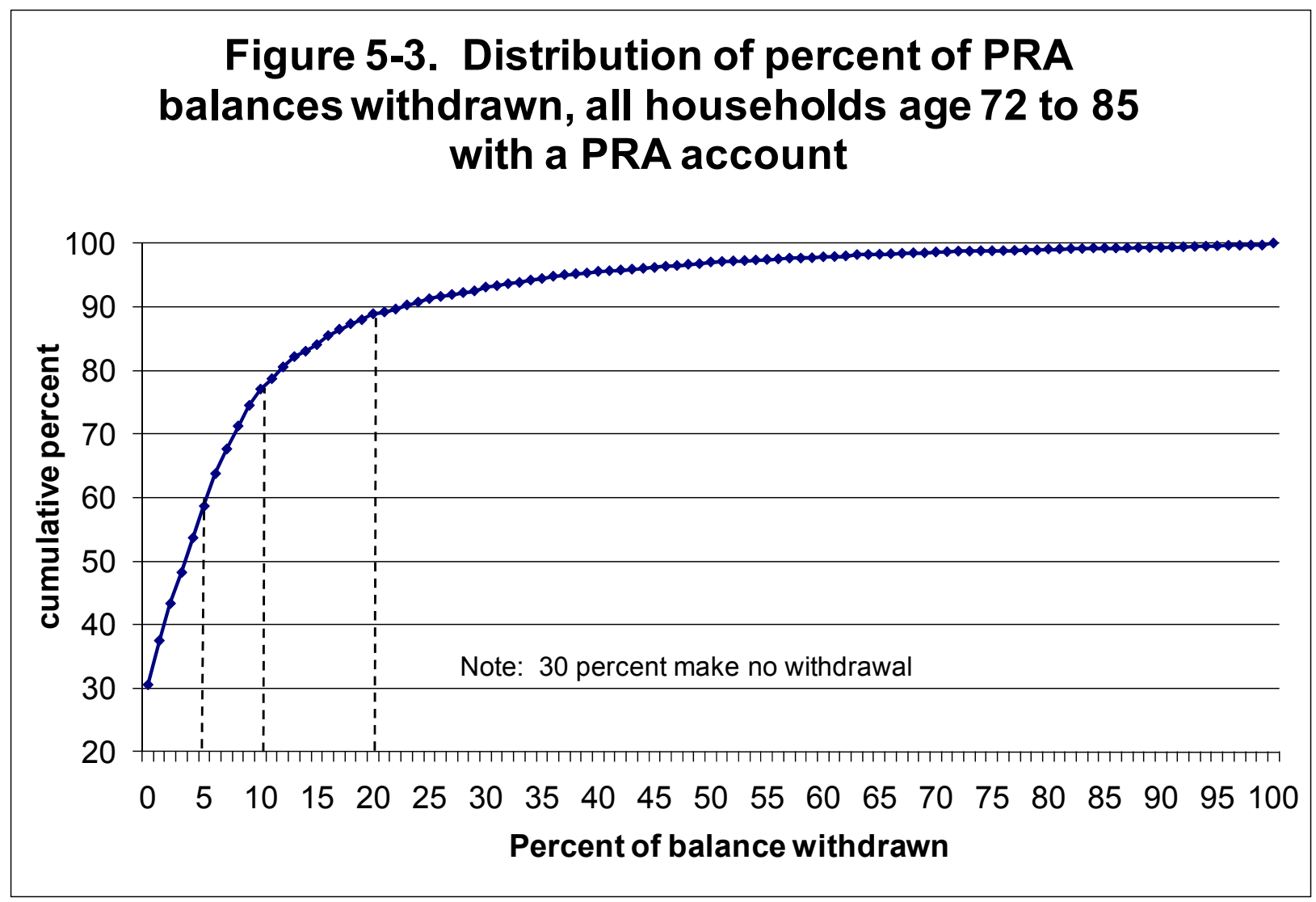

\section{Summary and Discussion}

We use data from the SIPP and the HRS to investigate withdrawals from personal retirement accounts (PRAs). We find a relatively modest rate of withdrawals prior to the age at which households are required to take minimum required distributions. Only seven percent of PRA-owning households between the ages of 60 and 69 take annual distributions of more than ten percent of their PRA balance, and only 17 percent of PRA households in this age group make any withdrawal in a typical year. The rate of distributions rises sharply after age $701 / 2$, when minimum distributions are required. The proportion of PRA-owning households making a withdrawal jumps to over 60 percent by age 71 , and crosses 70 percent a few years later. The sharp increase in withdrawals when distributions become mandatory suggests that many households in their early 70 s would not make withdrawals if it were not for the RMD rules.

The low rate of withdrawals from PRAs during our sample period, 1997-2005, combine with investment returns to PRA assets and contributions by some stillemployed PRA-owning households to generate an upward-sloping pattern of average PRA balances by age. Rather than declining in value after households retire and begin to finance retirement consumption, our findings suggest that PRA balances continue to grow through at least age 85, although the rate of growth is slower at older ages than at younger ages. On average, households age 60 to 69 with PRA accounts withdraw only about two percent of their account balances each year, considerably less than the rate 
of return on account balances. Even at older ages-after the required minimum distribution age--the percentage of balances withdrawn remains at about five percent which, for most years in our sample, was below the average return on PRA assets.

While average withdrawal rates are low, there is substantial heterogeneity across households, and some withdraw a significant proportion of PRA assets. Among households headed by someone between the ages of 60 and 69 , roughly ten percent of PRA owners make an annual withdrawal of five percent or more of their PRA assets, and about seven percent withdraw more than ten percent of assets. At ages 72 and older, after required distributions begin, 59 percent of households withdraw less than five percent of their PRA balance in a typical year, and 77 percent withdraw less than 10 percent of balance. On the other hand, eleven percent of those over the age of 72 withdraw more than twenty percent of their balance. We view these results as consistent with a general pattern of conserving PRA assets for most households.

There are substantial differences not just in withdrawal rates but also in PRA balances across households. While we estimate that only eight percent of households in the lowest decile of non-PRA wealth, income, and health status have a PRA as they approach retirement, about 80 percent of households in the top decile of non-PRA wealth, income, and health status have such accounts. We find that even after controlling for other assets, households in poor health are less likely than those in good health to have a PRA. With regard to withdrawal behavior, we find that among households approaching retirement, whether a withdrawal is made varies greatly with the PRA balance; households with higher balances are more likely to make a withdrawal than those with lower balances. Among those who make a withdrawal, the PRA balance is the most important determinant of the proportion of assets withdrawn.

We note two important limitations of our current analysis. First, withdrawals from PRAs do not necessarily translate into consumption: households may simply re-direct their assets from PRAs to other investment accounts. While there are substantial taxbased arguments for households prior to age $70 \frac{1}{2}$ to draw down non-PRA assets prior to PRA assets to fund consumption, whether households follow these rules is not clear. After age $701 / 2$, when households face required minimum distributions, it is more likely that some assets which are withdrawn from PRAs are transferred to other investment accounts. Integrating the analysis of PRA withdrawals with a broader investigation of household wealth at older ages is a key priority.

Second, our analysis excludes individuals who die between waves of the SIPP. Whether death-induced withdrawals should be aggregated with other withdrawals from PRAs depends on the purpose for which one is calculating the withdrawal rate. If the goal is to understand how PRAs are serving the retirement income needs of long-lived households, is seems appropriate to exclude those who die at an early age from the analysis. On the other hand, if the goal is to understand how long assets are held in the PRA system, which might be relevant for some types of tax analysis, then it is more important to recognize that death can be an important factor in generating withdrawals from the retirement saving system. 
One of the most important research priorities for future analysis is integrating our analysis of withdrawal patterns with explanations of why households choose to save. Our evidence is consistent with the view that most households conserve PRA assets for a "rainy day." Venti and Wise (2004) found something similar with respect to home equity, which tended to be held until a shock to family status occurred. They argued that households might want to remain in their home as long as possible, and they may also want to save their housing assets as a buffer against potentially large expenditures associated with illness or death of a spouse. Similar explanations may apply to PRA assets, which are a key source of liquid funds for many households. Households may want to preserve these funds for contingences such as entry to a nursing home or other large health care expenditures. Marshall, McGarry, and Skinner (2010) find that out-ofpocket health care costs when calculated based on exhaustive use of all information in the HRS are much larger than costs based on direct responses to questions about expenditures. They estimate that at the 95 percentile health care costs are about $\$ 100,000$ per person over a five-year period. EBRI (2009) estimates that men approaching retirement will need anywhere from $\$ 68,000$ to $\$ 173,000$ in assets to have a 50-50 chance of covering insurance premiums and out-of-pocket medical expenses in retirement and $\$ 134,000$ to $\$ 378,000$ if they want a 90 percent chance of covering these expenses. Asset reserves needed to fund medical expenses are even higher for women. The role of PRA accumulations in supporting precautionary saving objectives warrants further study.

Precautionary saving motives naturally raise two other related issues: the adequacy of retirement saving, and the role of annuitization in protecting households against longevity risk. With respect to the former issue, if households are holding PRAs and other assets to self-insure against late-life health shocks, many households that do not suffer major health shocks may die holding substantial asset balances, and appear on some metrics to have "over-saved" for retirement. In the presence of selfinsurance, however, this interpretation may be misplaced. Our results do not inform this issue, or the question of whether households are drawing down their wealth in retirement at the appropriate rate. But they could provide clues for further investigation.

Similarly, if households are concerned about late-life expenditure risks, they may choose not to annuitize all or even most of their wealth at retirement. The lack of annuitization of most PRA assets has attracted attention from researchers and policymakers, but the optimal degree of annuitization must depend on the risks that households are attempting to insure against, and the set of assets - including housing equity - that households can draw on in the event of adverse outcomes. Having some liquid assets to draw on in an emergency is valuable, and for many households PRA assets may be the single largest source of liquid assets. The role of PRA assets in supporting the diverse array of potential financial needs in retirement is a topic that warrants further attention, particularly as the maturing defined contribution pension system makes PRA assets a more important component of household wealth at retirement. 


\section{References}

Banks, James, Richard Blundell, Zoe Oldfield, and James Smith (2007), "Housing Price Volatility and Downsizing in Later Life," NBER Working Paper 13496.

Bershadker, Andrew and Paul A. Smith (2006), "Cracking Open the Nest Egg: IRA Withdrawals and Retirement Finance," Working Paper, US Department of the Treasury.

Brady, Peter, Sarah Holden and Erin Short (2009), "The U.S. Retirement Market 2008," Research Fundamentals 18 (5). Washington: Investment Company Institute.

Bryant, Victoria L., Sarah Holden, and John Sabelhaus (2010), "Qualified Retirement Plans: Analysis of Distribution and Rollover Activity," mimeo, Department of Economics, University of Maryland.

Bryant, Victoria L. and Peter J. Sailer (2006), "Accumulation and Distribution of Individual Retirement Arrangements, 2001-2002," Statistics of Income Bulletin (Spring), 90-101.

Copeland, Craig (2009), "Individual Account Retirement Plans: An Analysis of the 2007 Survey of Consumer Finances, with Market Adjustments to June 2009," EBRI Issue Brief 333.

Davidoff, Thomas (2007), "Illiquid Housing as Self-Insurance, The Case of Long-Term Care." Forthcoming Journal of Public Economics.

Employee Benefit Research Institute (2009), "Savings Needed for Health Expenses in Retirement: An Examination of Persons Ages 55 and 65 in 2009," EBRI Notes 30 (number 6).

French, Eric, Phil Doctor, and Olesya Baker (2007), "Asset Rundown After Retirement: The Imporance of Rate of Return Shocks," Federal Reserve Bank of Chicago Economic Perspectives (Q2), 48-65.

Holden, Sarah and Daniel Schrass (2010a), "The Role of IRAs in U.S. Households' Saving for Retirement, 2010", Research Fundamentals 19 (8). Washington: Investment Company Institute.

Holden, Sarah and Daniel Schrass (2010b), "Appendix: Additional Data on IRA Ownership in 2010," , Research Fundamentals 19 (8A). Washington: Investment Company Institute.

Hurd, Michael (2002), "Portfolios of the Elderly," in L. Guiso, M. Haliassos, and T. Jappelli, eds., Household Portfolios. Cambridge: MIT Press, 431-472.

Hurd, Michael and Susann Rohwedder, "Wealth dynamics and Active Saving at Older Ages: Do They Add UP?" mimeo, RAND.

Love, David, Michael Palumbo and Paul Smith (2007), "The trajectory of Wealth in retirement," Journal of Public Economics 93 (1), 191-208.

Love, David and Paul Smith (2007), "Measuring Dissaving Out of Retirement Wealth," mimeo, Williams College.

Marshall, Samuel, Kathleen McGarry, and Jonathan Skinner (2010), "The Risk of Outof-Pocket Health Care Expenditure at End of Life," NBER Working Paper 16170.

Megbolugbe, Issac, Jarjisa Sa-Aadu, and James Shilling (1997), "Oh Yes, the Elderly Will Reduce Housing Equity Under the Right Circumstances," Journal of Housing Research 8 (1), 53-74. 
Poterba, James, Steven Venti and David Wise (2010a), "Family Status Transitions, Latent Health, and the Post-Retirement Evolution of Assets," in D. Wise, ed., Explorations in the Economics of Aging. Chicago: University of Chicago Press (forthcoming). (also NBER Working Paper No. 15789).

Poterba, James, Steven Venti, and David Wise (2010b), "The Asset Cost of Poor Health," NBER Working Paper 16389.

Sabelhaus, John (2000), "Modeling IRA Accumulation and Withdrawals," National Tax Journal 53 (December), 865-876.

Sabelhaus, John and Daniel Schrass (2009), "The Evolving role of IRAs in U.S. Retirement Planning", Research Fundamentals 15 (3). Washington: Investment Company Institute.

Venti, Steven and David Wise (1990), "But They Don't Want to Reduce Housing Equity." in D. Wise, ed., Issues in the Economics of Aging. Chicago: University of Chicago Press, 13-29.

Venti, Steven and David Wise (2001), "Aging and Housing Equity." in O. Mitchell, Z. Bodie, P. Hammond, and S. Zeldes, eds., Innovations for Financing Retirement. Philadelphia: University of Pennsylvania Press. 254-281.

Venti, Steven and David Wise (2004), "Aging and Housing Equity: Another Look," in D. Wise, ed., Perspectives in the Economics of Aging. Chicago: University of Chicago Press, 127-175. 